University of California, Hastings College of the Law UC Hastings Scholarship Repository

Faculty Scholarship

1980

\title{
Dealing with Incompetent Counsel- The Trial Judge's Role
}

William W. Schwarzer

UC Hastings College of the Law, schwarzw@uchastings.edu

Follow this and additional works at: https://repository.uchastings.edu/faculty_scholarship

\section{Recommended Citation}

William W. Schwarzer, Dealing with Incompetent Counsel- The Trial Judge's Role, 93 Harv. L. Rev. 633 (1980).

Available at: https://repository.uchastings.edu/faculty_scholarship/1340

This Article is brought to you for free and open access by UC Hastings Scholarship Repository. It has been accepted for inclusion in Faculty Scholarship

by an authorized administrator of UC Hastings Scholarship Repository. For more information, please contact wangangela@uchastings.edu. 


\section{HARVARD LAW REVIEW}

\section{DEALING WITH INCOMPETENT COUNSEL - THE TRIAL JUDGE'S ROLE}

\section{William W Schwarzer*}

Constitutional principles as well as our commitment to the adversary system require competent performance by trial counsel. In this Article, Judge Schwarzer argues that the traditional remedies for ineffective performance - direct and collateral review of trial lawyers' conduct or malpractice actions - do not adequately ensure that attorneys competently represent their clients' interests. Rather, direct action by the trial judge to assure the competence of trial counsel is both desirable and necessary. Judge Schwarzer makes specific suggestions to guide the trial judge's efforts to secure adequate performance.

Responses to the problem of incompetent counsel are also considered in this issue in Note, Identifying and Remedying Ineffective Assistance of Criminal Defense Counsel: A New Look After United States v. Decoster. This Note focuses on judicial supervision of defense counsel performance at the pretrial stage. The two pieces may profitably be read together.

NADEQUATE performance of trial lawyers has become a growing concern to the bench, the bar, and the public." This concern is reflected in a variety of ways. Courts reviewing criminal convictions are examining the adequacy of the defendant's representation more closely and under more exacting standards. ${ }^{2}$ Damage actions for lawyers' malpractice are more common. ${ }^{3}$ The organized bar is beginning to look at incompetence as a possible ground for discipline. ${ }^{4}$ Clinical

* United States District Judge for the Northern District of California. The assistance of Jack Londen and Gail Ruetten Lopes, members of the California Bar, and Noel M. Lawrence and Brian C. Johnson, is gratefully acknowledged.

'See, e.g., Burger, The Special Skills of Advocacy: Are Specialized Training and Certification of Advocates Essential to Our System of Justice?, 42 FORDHAM L. REV. 227 (1973).

2 See p. 641 infra.

${ }^{3}$ See, e.g., Schmidman \& Salzler, The Legal Malpractice Dilemma: Will New Standards of Care Place Professional Liability Insurance Beyond the Reach of the Specialist?, 45 U. CIN. L. REv. 54I (1976); Comment, New Developments in Legal Malpractice, 26 AM. L. REV. 408 (1977).

${ }^{4}$ For example, until recently the California Supreme Court recognized only gross negligence and willful inattention to a client's affairs as a ground for discipline or disbarment. See, e.g., Ridley v. State Bar, 6 Cal. 3d 55I, 493 P.2d I05, 99 Cal. Rptr. 873 (1972) (en banc). But in 1975, the Court approved amendments to the 
programs to improve the quality of trial advocacy are receiving increasing attention, both in the law schools and outside. ${ }^{5}$ And the Judicial Conference of the United States has approved recommendations for the establishment of minimum standards of competence for attorneys practicing in the federal courts. ${ }^{6}$

While the dimensions of the problem are in dispute, surveys indicate that judges rate the overall performance of around one-tenth of the lawyers appearing before them as less than adequate and prejudicial to their client's cause. ${ }^{7}$ Whatever the dimensions, the problem is to some extent inherent in the conditions under which justice is administered. Because of the pressures of staggering case loads and limited resources, the criminal justice system frequently produces marginal performances by counsel. ${ }^{8}$ Criminal defense work tends not to attract

Rules of Professional Conduct including a new rule 6-1or requiring that legal services be provided competently. Under this rule, an attorney who willfully or habitually performs services lacking the learning and skill ordinarily possessed by lawyers in good standing performing such services, or who fails to use reasonable diligence and his best judgment, may be subject to discipline. The attorney's good faith is to be considered in determining whether discipline is warranted. CAL. R. CT. 680.

${ }^{5}$ See Gee \& Jackson, Bridging the Gap: Legal Education and Lawyer Competency, I977 B.Y.U. L. REV. $695,759,88 \mathrm{I}-92$.

${ }^{6}$ See Final Report of the Comm. to Consider Standards for Admission to Practice in the Federal Courts to the Judicial Conference of the United States (I979). See also Report and Tentative Recommendations of THE COMM. TO CONSIDER STANDARDS FOR ADMISSION TO PRACTICE IN THE FEDERAL CoURTS to THE JUdicial CONFERENCE of THE UNited STATES (I978) [hereinafter cited as DeVITT COMM. REP.].

${ }^{7}$ In a study conducted by the Federal Judicial Center in 1977 , questionnaires were sent to all 476 federal district judges. In answer to the question, "Do you believe that there is, overall, a serious problem of inadequate trial advocacy by lawyers with cases in your court?," 41\% of the 366 who responded answered "yes," 59\% answered "no." The judges rated the performance of $8.6 \%$ of the lawyers covered by the survey as less than adequate. More than half said that the most frequent consequence of inadequacy is that clients' interests are not fully protected. A. PARTridge \& G. Bermant, The Quality of AdVoCaCy in THE Federal Courts 30-43 (1978).

A survey conducted by the American Bar Foundation in 1975 arrived at similar conclusions. Based on responses from 1,422 state and federal judges throughout the country, it found that $13 \%$ of individual trial performances were rated less than minimally competent and that in about the same percentage of cases, the incompetence of counsel had significantly prejudiced the rights of litigants. Maddi, Trial Advocacy Competence: The Judicial Perspective, AM. B. Foundation Research J. 105, I18 (I978).

This Article deals with "competence" in the sense of the effective and diligent use of the lawyer's professional skills. It does not address manifestations of incompetence arising from other causes, such as misconduct or breach of other professional obligations, nor does it deal with the administering of sanctions, such as professional discipline or contempt.

${ }^{8}$ For a bleak description of the operation of the system, see Bazelon, The Defective Assistance of Counsel, 42 U. CIN. L. REV. I, I-I7 (1973); Comment, Liberal Review 
the more competent lawyer and, because of economic considerations, is often performed on an assembly line basis. ${ }^{9}$ Economics affect the quality of civil work as well. The cost of litigation has risen beyond the means of most individuals and of businesses of modest size, and lawyers often must choose between pricing their services out of the market and being inadequately prepared. It is also possible that because vast numbers of new lawyers have been admitted to the bar in recent years, more trial work is in the hands of relatively inexperienced counsel. ${ }^{10}$

The client who suffers the consequences of an inadequate performance has some remedies. A criminal defendant may appeal or seek post-conviction relief by writ of habeas corpus. In addition, any client can sue his lawyer for damages caused by malpractice. But, as we shall see, courts are reluctant to reverse convictions on the ground of incompetence of counsel, and malpractice damages are costly and difficult to recover and may well be inadequate. ${ }^{11}$ The questions therefore arise whether trial judges can and should monitor the performance of counsel and take action sua sponte when it is necessary, ${ }^{12}$ whether to do so would be consistent with the

of Defense Counsel's Performance: The Normal Competency Test, 1976 U. ILL. L.F. 407, 408-ri (I976).

${ }^{9}$ See, e.g., Argersinger v. Hamlin, 407 U.S. $25,34-36$ (1972); id. at 57 n.2I (Powell, J., concurring); Bazelon, supra note 8.

${ }^{10}$ Even with the implementation of proposals for improved trial advocacy training, the judge's problem of how to deal with incompetent counsel is not likely to disappear. See, e.g., DEvitT CoMm. REP., supra note 6, supp. A at 14:

It seems appropriate to note, however, that even if fully effective remedies are fashioned for the causes related to the competence and proficiency of counsel, problems of substandard representation of litigants will remain and may even grow, unless remedies are also fashioned for causes relating to high costs of litigation and causes relating to effective judicial supervision of trials.

(Emphasis added).

${ }^{11}$ See pp. $642-49$ infra.

12 Making judgments about attorney competence is not foreign to the trial judge. He routinely acts on matters that involve questions of counsel's competence - the appointment of counsel for indigent defendants, the imposition of sanctions for violations of rules and orders, the disqualification of counsel when there are conflicts of interest, the certification of a class action, and the setting of fees. Typically, however, the trial judge will act on the motion of a party, rather than sua sponte, and to implement a specific mandate, such as an order, statute, or rule. Furthermore, these motions usually do not involve direct challenges to a lawyer's competence. See p. 660 infra. The intervention contemplated here is novel, since it would generally be sua sponte, and would be a direct response to perceived incompetence.

Authority for intervention of this kind derives from the judge's power to control the proceedings before him. That power extends to the regulation of practice in his court, including the admission of attorneys, supervision of their conduct, and imposition of sanctions and discipline. See Hull v. Celanese Corp., 513 F.2d 568, 571 (2d Cir. 1975). Typical of rules reflecting this authority is rule IIO-3 of the Local Rules 
adversary process and with relevant constitutional principles, and how and under what circumstances a judge might act. These questions have received little attention, most previous discussion having focused on appellate and habeas corpus remedies. ${ }^{13}$

This Article addresses some of the questions raised by sua sponte intervention. First, it argues that prophylactic action by the trial judge is consistent with our commitment to the adversary system and with relevant constitutional principles. It also argues that those principles require the judge to take steps to ensure that counsel is competent. Then, it rejects the contention that the alternatives to intervention - direct and collateral review, and malpractice actions - are adequate. Finally, having concluded that the trial judge should monitor lawyers' performances, it develops guidelines for intervention in both criminal and civil litigation.

\section{The Implications of the Adversary Process}

We are committed to the adversary process as the best, even if imperfect, method of finding the truth and administering justice. ${ }^{14}$ "Truth," Lord Eldon said, "is best discovered by powerful statements on both sides of the question." 15 A critical assumption underlying our commitment to this process

of the United States District Court, Northern District of California. The judge is expected to act, unilaterally if necessary, to enforce the professional obligations of attorneys. See, e.g., In re Abrams, 521 F.2d 1094, Iog9 (3d Cir.), cert. denied, 423 U.S. 1038 (1975); In re Carroll, 416 F.2d 585, 587 (Ioth Cir. 1969). Among these obligations is the duty to adhere to the ABA Canons of Professional Ethics and the ABA Code of Professional Responsibility. Canon 6 states, "Because of his vital role in the legal process, a lawyer should act with competence and proper care in representing clients." Disciplinary Rule 6-IOI further defines this obligation:

(A) A lawyer shall not:

(I) Handle a legal matter which he knows or should know that he is not competent to handle, without associating with him a lawyer who is competent to handle it.

(2) Handle a legal matter without preparation adequate in the circumstances.

(3) Neglect a legal matter entrusted to him.

${ }^{13}$ See, e.g., Bines, Remedying Ineffective Representation in Criminal Cases: Departures from Habeas Corpus, 59 VA. L. REV. 927, 932, 943-45 (1973).

14 The adversary system is not without its critics, however. See, e.g., Frankel, The Search for Truth: An Umpireal View, I23 U. PA. L. REv. I031, I032 (1975) (contending that the system "rates truth too low among the values that institutions of justice are meant to serve"). Judge Frankel sees the judge's task to be "to promote through the trial an objective search for the truth," id. at I035, and objects "that our system does not allow much room for effective or just intervention by the trial judge in the adversary fight about the facts," id. at ro42.

${ }^{15}$ Quoted in Kaufman, Does the Judge Have A Right to Qualified Counsel?, $6 \mathrm{I}$ A.B.A.J. 569 (1975). 
is that it will be operated by competent lawyers. Lawyers must be able to make the innumerable decisions which, although often procedural, shape the litigation and direct it toward its eventual outcome. ${ }^{16}$ Criminal defense counsel must decide or recommend whether to plead guilty, waive the right to a jury, take the stand, object to evidence, and take an appeal. Counsel in civil litigation must decide which claims or defenses to assert, what forum to select, what discovery to conduct, and what scope to give to the trial. Another assumption underlying our commitment to the adversary system $s$ is that each lawyer will present the strongest statement that can fairly be made for his side of the case. ${ }^{17}$ The lawyer's ability to marshal and present facts and law to support a client's cause is critical to the process. ${ }^{18}$

As Justice Brennan observed in his dissent in Wainwright v. Sykes, we "traditionally have resisted any realistic inquiry into the competency of trial counsel," preferring instead "to indulge the comfortable fiction that all lawyers are skilled or even competent craftsmen in representing the fundamental rights of their clients." 19 The facts refute this fiction. Putting aside the cases of marginal performance or simple human error, trial counsel at times perform with such manifest incompetence that litigants' rights are prejudiced. When that occurs, the adversary process has effectively ceased to function. The judge then faces the choice of taking over from counsel or allowing the case to stumble toward a fortuitous result.

Intervention does present certain undeniable difficulties. It requires the judge to depart from his traditional neutral rule. Moreover, inquiry into counsel's litigation strategy could jeopardize the confidential relationship between counsel and client and impair the adversary process. ${ }^{20}$ Indeed, the mere threat

${ }^{16}$ See, e.g., Brown v. Commonwealth, 551 S.W.2d 557, 559 (Ky. I977).

17 See ABA Comm. on Standards of Judicial administration, Standards RELATING To TRIAL CoURTS 5 (1976) ("The premise of the adversary system is that each party has the incentive and ability to present all pertinent legal and factual submissions supportive to his position and that the parties' combined efforts enable the court to make a fully informed decision.") [hereinafter cited as TRIAL COURTs].

${ }^{18}$ For if, as Chief Judge Kaufman writes, "lawyers fail as advocates for want of skill or dedication, then judges surely will fail as well, and the coin of justice will be debased beyond recognition." Kaufman, The Court Needs a Friend in Court, 60 A.B.A.J. 175 (1974). See also United States v. Wright, 568 F.2d I42, I43 (gth Cir. 1978) ("It is the duty of counsel to assist the court, as well as the client. . . .").

19 See Wainwright v. Sykes, 433 U.S. 72, II7-I8 (I977) (Brennan, J., dissenting).

${ }^{20} \mathrm{See}$, e.g., United States v. Decoster, No. 72-1283, slip op. at 22 (D.C. Cir. July 10, 1979) (en banc):

[The court] must be wary lest its inquiry and standards undercut the sensitive relationship between attorney and client and tear the fabric of the adversary system. ... For the law to encourage a wide-ranging inquiry, even after trial, 
of intervention may have a chilling effect on the freedom of counsel to act in the manner which he thinks will best serve his client, whether the court approves or not. ${ }^{21}$ But the interest in preserving the adversary process militates more strongly in favor of intervention than against it. We long ago came to accept that process as more than a game and the judge's role in it as more than that of a moderator charged with seeing that the rules of the game are observed. ${ }^{22}$ Inasmuch as the administration of justice is the judge's ultimate responsibility, he cannot be indifferent to events which diminish the quality of justice in his court. ${ }^{23}$ The propriety of sua sponte intervention is unquestioned when counsel's conduct disrupts the proceeding. ${ }^{24}$ Its propriety should be equally clear when counsel is manifestly incompetent. For the effect of incompetence on the administration of justice, even if less dramatic, is likely to be just as destructive.

When incompetence is so serious as to lead to reversals on appeal or to subsequent malpractice actions, the administration of justice is destabilized. Reversals and damage awards stemming from a lawyer's failure to perform adequately impair the orderliness, predictability, and fairness of the judicial process and undermine public confidence. Even where lawyers' incompetence is not so serious as to justify reversal, the administration of justice suffers if one side is not adequately represented and inadvertent defaults occur.

The concern for lawyer competence, therefore, is not an

into the conduct of defense counsel would undercut the fundamental premises of the trial process and transform its essential nature.

See also Mitchell v. United States, 259 F.2d 787, 792-93 (D.C. Cir.), cert. denied, 358 U.S. 850 (1958).

21 That the adversary system at times expects more of counsel than the trial judge would like was recognized by the Seventh Circuit in In re Dellinger, 46r F.2d 389, 400 (7th Cir. 1972) ("Attorneys have a right to be persistent, vociferous, contentious, and imposing, even to the point of appearing obnoxious, when acting in their client's behalf. An attorney may with impunity take full advantage of the range of conduct that our adversary system allows.").

${ }^{22}$ See, e.g., Quercia v. United States, 289 U.S. 466,469 (r933) ("In a trial by jury in a federal court, the judge is not a mere moderator, but is the governor of the trial for the purpose of assuring its proper conduct and of determining questions of law."). See also United States v. Powe, 59I F.2d 833, 842-43 (D.C. Cir. 1978).

${ }^{23}$ abA Standards Relating to the Administration of Criminal Justice, ThE FunCtion OF THE TRIAL JUDGE $\S$ I.I(a) I67 (I974) ("The adversary nature of the proceedings does not relieve the trial judge of the obligation of raising on his own initiative, at all appropriate times and in an appropriate manner, matters which may significantly promote a just determination of the trial.") (hereinafter cited as TruaL JUDGE]. See also id. at I63.

${ }^{24}$ See, e.g., United States v. Dinitz, 424 U.S. 600, 612 (1976) (Burger, C.J., concurring); United States v. Dinitz, 538 F.2d I2I4 (5th Cir. 1976), cert. denied, 429 U.S. Iro4 (1977). 
exercise in elitism. If the process by which justice is administered is to work as intended, lawyers must perform their functions adequately. When it appears in the course of litigation that a lawyer's performance is falling short, it should be the trial judge's responsibility, as the person responsible for the manner in which justice is administered in his court, to take appropriate action. The question confronting the trial judge, therefore, is not whether intervention can be reconciled with the adversary process, but how to exercise the discretion to intervene so as to accommodate the competing demands of that process. ${ }^{25}$

\section{The Impact and Interplay of Constitutionad RIGHTS}

Our dedication to the due process of law matches the commitment to the adversary system. A person with legitimate grievances is entitled to a meaningful hearing, including adequate notice and an opportunity to confront adverse witnesses and present evidence and argument on his behalf. ${ }^{26}$ The judge cannot be indifferent to a lawyer's incompetence; when the fairness of a trial is frustrated or jeopardized by manifest incompetence of counsel, due process may be denied as surely as if no hearing had been held. ${ }^{27}$

Principles of due process, applicable to legal proceedings generally, are enlarged and reinforced by the sixth amendment governing criminal trials. The criminal defendant is entitled to receive a speedy and public trial before a fairly chosen jury, to be given notice of the charges against him, to confront the witnesses against him, to compel the attendance of witnesses in his favor, and to have the assistance of counsel. ${ }^{28}$ These

${ }^{25}$ See United States v. Decoster, No. 72-1283, slip op. at 22-23 (D.C. Cir. July ro, 1979) (en banc) ("Efforts to improve the performance of defense counsel should not imperil that protection [provided by the adversary system for the rights of the accused].").

${ }^{26}$ See, e.g., Goldberg v. Kelly, 397 U.S. 254, 267-68 (1970). More generally, the trial must be fair. See Faretta v. California, 422 U.S. 806, 8I9 n.I5 (I975); Lutwak v. United States, 344 U.S. 604 , 6r9 (r953).

${ }^{27}$ See, e.g., White v. Ragen, 324 U.S. 760 (1945); Powell v. Alabama, 287 U.S. 45 (1932); cf. Goldberg v. Kelly, 397 U.S. 254, 270-71 (I970) (right to be heard comprehends right to be heard by retained counsel).

${ }^{28}$ U.S. CONST. amend. VI provides:

In all criminal prosecutions, the accused shall enjoy the right to a speedy and public trial, by an impartial jury of the State and district wherein the crime shall have been committed, which district shall have been previously ascertained by law, and to be informed of the nature and cause of the accusation; to be confronted with the witnesses against him; to have compulsory process for obtaining witnesses in his favor, and to have the Assistance of Counsel for his defence. 
rights are absolute and the denial of any of them results in automatic reversal. ${ }^{29}$

The criminal defendant's right to the assistance of counsel has evolved significantly in the last fifty years. Since Powell $v$. Alabama, ${ }^{30}$ which held that the defendant is entitled to "effective aid in the preparation and trial of the case," 31 the Supreme Court has substantially enlarged the scope of that right. As now interpreted, the right to counsel is binding on state as well as federal courts, ${ }^{32}$ extends to all cases in which the defendant is ultimately imprisoned, ${ }^{33}$ and is not surrendered in the absence of a knowing and voluntary waiver. ${ }^{34}$ Structural inhibitions on the effective assistance of counsel, such as rules or orders restricting counsel from conferring with the defendant during a recess between direct and cross-examination, ${ }^{35}$ barring the defendant from giving testimony by way of direct examination by his counsel, ${ }^{36}$ or denying defense counsel a closing argument in nonjury cases, ${ }^{37}$ have been held to be categorically prohibited regardless of whether they are shown to be prejudicial. Late appointment of $\operatorname{counsel}^{38}$ or

${ }^{29}$ See, e.g., Gideon v. Wainwright, 372 U.S. 335 (1963); $c f$. Chapman v. California, 386 U.S. 18,23 n.8 ( 1967 ) (dictum) (some constitutional errors, but not including denial of the right to counsel, may be deemed harmless, not requiring automatic reversal).

30287 U.S. 45 (1932).

${ }^{31} \mathrm{Id}$. at 7r. In a classic statement on the need for counsel, the Court said, in part: "Even the intelligent and educated layman ... lacks both the skill and knowledge adequately to prepare his defense, even though he [has] a perfect one. He requires the guiding hand of counsel at every step in the proceedings against him." Id. at 69. See also Johnson v. Zerbst, 304 U.S. 458, 462-63 (1938).

32 See, e.g., Gideon v. Wainwright, 372 U.S. 335 ( 1963 ).

${ }^{33}$ See, e.g., Argersinger v. Hamlin, 407 U.S. 25 (1972); Gideon v. Wainwright, 372 U.S. 335 (rg63). See also Scott v. Illinois, 440 U.S. 367 (1979).

${ }^{34}$ See Johnson v. Zerbst, 304 U.S. 458,465 (1938).

The Supreme Court has held that a defendant has the right to waive counsel altogether, requiring only that his decision be made voluntarily and intelligently. See Faretta v. California, 422 U.S. 806, 832-35 (I975). See also United States v. Garafola, 428 F. Supp. 620, 623-24 (D.N.J. 1977), aff'd. sub nom. United States v. Dolan, 570 F.2d II77 ( $3 \mathrm{~d}$ Cir. I978). The recognition of this right, by acknowledging the defendant's autonomy, is in tension with the premise underlying Powell v. Alabama and its progeny that laymen are unable adequately to conduct their own defense. See, e.g., Powell v. Alabama, 287 U.S. 45,69 (I932). It does not, however, limit the trial judge's responsibility or authority to ensure, that when the defendant is represented by counsel, that representation be effective. See, e.g., McMann v. Richardson, 397 U.S. 759, 77 I (I970). See generally Faretta v. California, 422 U.S. 806, 832-34, 838-40 (Burger, C.J., dissenting).

${ }^{35}$ See Geders v. United States, 425 U.S. 80 (1976).

${ }^{36}$ See Ferguson v. Georgia, 365 U.S. 570, 596 (x96r). See also Brooks v. Tennessee, 406 U.S. 605 (1972).

${ }^{37}$ See Herring v. New York, 422 U.S. 853 (1975).

${ }^{38}$ See Powell v. Alabama, 287 U.S. 45, 7I (1932); Chambers v. Maroney, 399 U.S. 42, 55-60 (1970) (Harlan, J., concurring and dissenting). 
representation by counsel with conflicting interests ${ }^{39}$ may, depending on the circumstances, deny the defendant effective assistance. Finally, effective assistance may be denied where representation by counsel is so lacking in diligence and competence as to adversely affect the defendant's rights. ${ }^{40}$

The frequency with which the issue of ineffective representation has arisen in recent cases before reviewing courts should alert trial courts to the need to monitor counsel's performance. These cases clearly suggest that the trial courts have the duty and the authority to protect the right to effective counsel. That the trial judge should not hesitate to act to assure the competent performance of counsel seems to be precisely what the Supreme Court had in mind in McMann v. Richardson, ${ }^{41}$ when it said:

[W]e think the matter [whether counsel acted within the range of competence demanded of attorneys in criminal cases], for the most part, should be left to the good sense and discretion of the trial courts with the admonition that if the right to counsel guaranteed by the Constitution is to serve its purpose, defendants cannot be left to the mercies of the incompetent counsel, and that judges should strive to maintain proper standards of performance by attorneys who are representing defendants in criminal cases in their courts. ${ }^{42}$

${ }^{39}$ See Holloway v. Arkansas, 435 U.S. 475, 48I-87 (1978); Glasser v. United States, 315 U.S. $60,69-76$ (1942).

${ }^{40}$ Although the Supreme Court has not yet spoken authoritatively, a flood of decisions on the issue has been loosed by federal courts of appeals in the last to years. The traditional test, whether counsel's performance rendered the trial a "farce and mockery of justice," has now been abandoned by all but three of the circuits. The newly adopted standards differ in semantic detail from circuit to circuit but generally appear to be derived from the opinion of the Court in McMann v. Richardson, 397 U.S. 759, 77r (1970), where it was stated that legal advice must be "within the range of competence demanded of attorneys in criminal cases." The most recent and comprehensive review and analysis of the state of the law regarding standards for appellate review of defense counsel's performance is found in the several opinions accompanying the en banc decision in United States v. Decoster, No. $7^{2-}$ I283 (D.C. Cir. July Io, I979), particularly Judge MacKinnon's concurring opinion. See note 42 infra. See generally pp. 642-45 infra.

${ }^{41} 397$ U.S. 759 ( 1970 ).

42 Id. at $77 \mathrm{I}$ (emphasis added). See also United States ex rel. Darcy v. Handy, 203 F.2d 407, 427 (3d Cir.) ("gross incompetence or faithlessness of counsel as should be apparent to the trial judge . . call[s] for action by him"), cert. denied, 346 U.S. 865 (I953); Monroe v. United States, 389 A.2d 8rI, 8 I6 (D.C.) ("the trial court ... has the duty to ensure that the assistance . . rendered to an accused comports with at least the minimum level of competence consistent with our standards of the fair administration of justice"), cert. denied, 439 U.S. 1006 (1978); People v. Medina, 44 N.Y.2d 199, 207, 375 N.E.2d 768, 772, 404 N.Y.S.2d 588, 592 (1978) ("Trial Judges have a continuing duty, not to be lightly eschewed, to see to it that the proceedings are conducted with solicitude for the essential rights of the accused. ..."). See also MacKenna v. Ellis, 280 F.2d 592, 600 (5th Cir. 1960), 


\section{The Adequacy of the Alternatives to INTERVENTION}

Reservations about having trial judges openly monitor the performance of counsel, and intervene when necessary, are likely to persist. They are founded on the traditional conception of the judge's role, buttressed by the belief that criminal defendants may be better protected against the shortcomings of counsel by subsequent judicial review, since appellate judges unaffected by the adversarial battle can evaluate counsel's performance more objectively. ${ }^{43}$ They are also supported by an assumption that malpractice actions provide an adequate relief to clients in both criminal and civil cases. It is therefore appropriate to examine the adequacy of these alternatives to intervention.

\section{A. Appellate Review of Convictions}

Although appellate review, founded on the reviewing court's general supervisory power over the lower courts, is broad in theory, it suffers from structural and doctrinal limitations which reduce its effectiveness as a remedy for the violation of the right to effective counsel. ${ }^{44}$ The structural limitations arise because an appellate court is bound by the record of the trial court; it lacks the benefit of observing counsel in action. As a result, most of the trial lawyer's prep-

modified, 289 F.2d 928 (5th Cir.) (en banc), cert. denied, 368 U.S. 877 (r96I); United States v. Rogers, 47 I F. Supp. 847,854 (E.D.N.Y. 1979).

A vigorous argument in support of trial judge intervention is made by Judge Bazelon in his recent dissenting opinion (joined by Chief Judge Wright) in United States v. Decoster, No. 72-I283 (D.C. Cir. July Io, I979), in which he states in part:

The real battle for equal justice, however, must be waged in the trenches of the trial courts. Although reversing criminal convictions can have a significant deterrent effect, an appellate court necessarily depends upon the trial courts to implement the standards it announces. No amount of rhetoric from appellate courts can assure indigent defendants effective representation unless trial judges - and ultimately defense counsel themselves - fulfill their responsibilities.

Slip op. at $38-4$ I.

${ }^{43}$ See, e.g., Gard, Ineffective Assistance of Counsel - Standards and Remedies, 4I Mo. L. REV. 483, 499-500 (1976). See also Comment, Sanctions Imposed by Courts on Attorneys Who Abuse the Judicial Process, 44 U. CHr. L. ReV. 619 (1977). ${ }^{44}$ Presumably federal appellate courts are on direct appeal able to pass on the adequacy of counsel in the exercise of their supervisory authority, independently of constitutional grounds. See Fay v. New York, 332 U.S. 26r, 287 (1947); McNabb v. United States, 3 I8 U.S. 332, 340 (r943); United States v. Decoster, No. 72-1283, slip op. at 20 (D.C. Cir. July ro, r979) (en banc); Bruce v. United States, 379 F.2d Ir 3 , I 7 (D.C. Cir. r967). The distinction between direct and collateral review, although theoretically valid, appears, however, to have had no practical impact on the scope of review of claims of ineffective representation. The courts seem generally to have looked to the sixth amendment as the basis for review. 
aration and performance will be difficult to evaluate. The lifeless and fragmentary appellate record ${ }^{45}$ will provide few insights into, and a poor perspective of counsel's knowledge of the law, capacity to analyze and plan, and ability to conduct effective direct and cross-examination of witnesses. This problem will be magnified to the extent that the lawyer was incompetent. In such a case, the record is likely to be particularly deficient.

Even assuming the appellate court has acquired an understanding of the proceedings below adequate to enable it to pass on the issue of competence, it faces the doctrinal problem of deciding what to do if it finds evidence of incompetence. This problem has received attention in recent years as courts have begun to adopt more stringent constitutional standards for evaluating counsel competence. As long as the courts adhered to the former standard, which required a finding that the trial amounted to a "farce or mockery" before a conviction would be reversed, ${ }^{46}$ the cases in which remand for a new trial was held justified were few but clearcut; a new trial was granted only when the accused had in effect been deprived of any trial at all. Since McMann $v$. Richardson, ${ }^{47}$ however, in which the Supreme Court seemed to approve the adoption of a minimum standard based on reasonable expectations of competence, most appellate courts have abandoned the "farce and mockery" rule for some type of reasonableness standard patterned on the language of the McMann decision. ${ }^{48}$ Giving content to such a standard is an elusive and subjective task.

While some courts have sought to establish guidelines to define what is minimally competent, most have recognized that the determination must depend on the circumstances of each case. ${ }^{49}$ Even if a standard for adjudicating claims of counsel

\footnotetext{
${ }^{45}$ See generally Bazelon, supra note 8 , at 38-40.

${ }^{46}$ See, e.g., Diggs v. Welch, I48 F.2d 667 (D.C. Cir.), cert. denied, 325 U.S. 889 (1945).

47397 U.S. 759 (1970).

${ }^{48}$ See note 40 supra.

${ }^{49}$ See, e.g., United States v. Decoster, No. 72-I283, slip op. at I4-16 (D.C. Cir. July Io, 1979) (en banc); Cooper v. Fitzharris, 586 F.2d I325, 1330 (9th Cir. 1978) (en banc), cert. denied, 440 U.S. 974 (1979). But see Marzullo v. Maryland, 56I F.2d 540 (4th Cir. 1977), cert. denied, 435 U.S. IOII (1978); Coles v. Peyton, 389 F.2d 224 (4th Cir.), cert. denied, 393 U.S. 849 (1968).

The majority in Decoster argues that when appellate review is limited to cases of "egregious" deficiencies of counsel, the law would "encourage a wide-ranging inquiry ... into the conduct of defense counsel [which] would undercut the fundamental premises of the trial process and transform its essential nature ... resulting [in] upheaval in the role of the trial judge." United States v. Decoster, slip op. at 22. Prophylactic action by the trial judge, as urged in this article, will serve to minimize the need for the kind of disruptive action the Decoster court feared.
} 
incompetence could be defined, courts might be loath to reverse judgments on this ground, believing that such an action would serve little useful purpose. Appellate decisions normally establish guidelines for trial court conduct; reversals serve as a deterrent against future departures from these guidelines by the lower court. Since trial judges customarily are thought to have little control over inadequate performance by counsel, appellate courts might decide that reversal would fail to serve that purpose. ${ }^{50}$

Probably the major limitation on the effectiveness of appellate review to vindicate a party's right to competent counsel is the rule that, in the absence of "plain error," the appellate court generally will not consider a ground raised for the first time on appeal. ${ }^{51}$ Thus, errors or omissions by trial counsel - such as a failure to make an objection, to raise a defense, or to request a jury instruction - are ordinarily barred as grounds for appeal unless the error can be demonstrated to have been so serious that prejudice to defendant resulted. In this fashion the appellate courts attempt to resolve the dilemma of incompetent counsel who, by creating the necessity for appeal, creates at the same time the bar to review. ${ }^{52}$

${ }^{50} \mathrm{See}$ Bines, supra note $\mathrm{53}$, at 945 . The author argues that appellate courts are less inclined to reverse convictions for errors which trial courts cannot control, such as lawyers' incompetence. While the author's analysis of appellate reasoning may be valid, his assumption that trial courts cannot deal with incompetence is, of course, in conflict with the thesis of this Article.

S1 FED. R. CRIM. P. 52(b); see, e.g., McKissick v. United States, 379 F.2d 754, 759 (5th Cir. I967). See also United States v. Atkinson, 297 U.S. 157, 160 (1936) ("In exceptional circumstances, especially in criminal cases, appellate courts, in the public interest, may, of their own motion, notice errors to which no exception has been taken, if the errors are obvious, or if they otherwise seriously affect fairness, integrity or public reputation of judicial proceedings."), quoted in Silber v. United States, 370 U.S. 717,718 (1962). Although most frequently applied in federal criminal appeals, the "plain error" rule may be invoked by the United States Supreme Court in any case. SUP. Cr. R. $40(\mathrm{r})(\mathrm{d})(2)$. Fundamental constitutional errors in state criminal appeals have been noticed for the first time during argument before the Supreme Court. See, e.g., Mapp v. Ohio, 367 U.S. $643,673-74$ nn.4-6 (rg6r) (Harlan, J., dissenting).

Courts have been more reluctant to notice plain error when counsel below was retained by the defendant than when counsel was appointed. Compare Borroto v. United States, 338 F.2d 60 (5th Cir. 1964), with United States v. Smith, 353 F.2d r66 (4th Cir. 1965). See also 3 C. Wright, Federal Practice and Procedure (Cruminal) § 856, at 375 ( $\mathrm{ig} 69$ ).

52 See, e.g., Wainwright v. Sykes, 433 U.S. 72, 104 (1977) (Brennan, J., dissenting); Cooper v. Fitzharris, 586 F.2d r325, r339-40 (9th' Cir. 1978) (Hufstedler, J., concurring and dissenting), cert. denied, $99 \mathrm{~S}$. Ct. I542 (1979). A survey of the cases decided by the Kentucky appellate courts in one year involving evidentiary issues disclosed some 28 types of procedural defaults, ranging from failure to object to incompetent evidence to failure to file a transcript of the record on appeal, and 
Nevertheless, a different rule would reduce the administration of justice to chaos. Judgments after trial would be robbed of finality if almost any tactical decision were subject to reexamination and any significant omission of counsel a ground for a new trial. Counsel would have little incentive to employ effective trial advocacy at the first trial since errors and defaults would provide the basis for a new trial. As a consequence, the trial courts, deprived of effective advocacy, would bear a greater burden and face increasing numbers of retrials. Finally, more defendants would go free because witnesses would become unavailable and memories would fade by the time the appeal is concluded.

\section{B. Review in Collateral Proceedings}

The impediments to review are even more formidable where the defendant seeks collateral relief. A criminal defendant can obtain such relief in federal court by petitioning for a writ of habeas corpus. The writ is available only where the petitioner is detained in violation of the Constitution, laws, or treaties of the United States. ${ }^{53}$ Although denial of the effective assistance of counsel provides a constitutional basis for review, and although most circuits have abandoned the farce and mockery standard for one based on what may reasonably be expected, no court has held collateral relief to be available simply upon a showing of ineffectiveness. Before granting a new trial, they have required a further demonstration that the ineffectiveness resulted in prejudice to the defendant or that it was likely to have had an effect on the outcome. ${ }^{54}$

These obstacles combine with other obstacles to collateral relief, which are based on respect for the functions performed by the trial courts, recognition of the need for finality, and

concluded that frequently "a significant part of a criminal appeal is resolved on some basis other than its merits." See Lawson, Presuming Lawyers Competent to Protect Fundamental Rights: Is it an Affordable Fiction?, $66 \mathrm{KY}$. L.J. 459, 464-66 (I978).

${ }^{53}$ See generally Bines, supra note $x_{3}$.

54 For a discussion of the various standards, see United States v. Decoster, No. 72-1283, slip op. at 4-39 (D.C. Cir. July ro, 1979) (en banc) (MacKinnon, J., concurring); id. at 4-39 (Robinson, J., concurring); id. at 5-8 (Bazelon, J., dissenting). See also Cooper v. Fitzharris, 586 F.2d I325, I33I-34 (9th Cir. 1978), cert. denied, 99 S. Ct. 1542 (1979); 586 F.2d at I334-4I (Hufstedler, J., concurring and dissenting).

It is likely that an adequate showing of prejudice will require proof of constitutional error so substantial that it could not be waived without the defendant's express consent. Analytically at least, the incompetence issue would then be moot. See, e.g., Wainwright v. Sykes, 433 U.S. 72, 92-94 (1977) (Burger, C.J., concurring) (distinguishing between waiver of substantial constitutional rights and decisions made during the trial). See also Bines, supra note 13 , at $966-67$. 
awareness of the perishable character of evidence. ${ }^{55}$ For example, failure to make a timely objection to a due process violation will generally be treated as a waiver. ${ }^{56} \mathrm{~A}$ failure to comply with state procedural requirements, such as a rule requiring that objections be made contemporaneously, will bar relief in the absence of a showing of cause and resulting prejudice. $^{57}$ A voluntary and intelligent guilty plea will cut off preexisting defenses and objections. ${ }^{58}$

This gloss on the federal habeas remedy underlines the crucial importance of competence of trial counsel. Although the availability of competent legal assistance is a premise underlying these rules, ${ }^{59}$ proving that the requisite degree of competence did not exist is, for the reasons discussed, a difficult task. Aware that counsel must make numerous tactical decisions in the course of the trial, courts will probably be reluctant to grant relief so long as the decision complained of is one which a competent attorney could have made, regardless of whether in the particular case it was the product of incompetence and adversely affected the defendant's rights. ${ }^{60}$

\section{Legal Malpractice Actions}

Thus, for a variety of reasons, appellate and collateral review do not obviate the need for prophylactic action by the trial court. Similarly, actions for damages based on legal malpractice are unlikely to provide effective relief to clients in either criminal or civil litigation. Even if the client is knowledgeable and sophisticated enough to recognize that his lawyer has failed him and that a legal malpractice action is available, ${ }^{61}$ and even if he has the initiative, endurance, and re-

s5 See, e.g., Wainwright v. Sykes, 433 U.S. 72, 88-9I (I977); Bines, supra note I3, at $935-45$.

${ }^{56}$ See Estelle v. Williams, 425 U.S. 50I (1976).

${ }^{57} \mathrm{See}$ Wainwright v. Sykes, 433 U.S. 72 (1977). See also id. at 95-96 (Stevens, $\mathrm{J}$., concurring) (competence of counsel may be relevant to the determination of "cause" and "prejudice").

58 See, e.g., McMann v. Richardson, 397 U.S. 759 (1970). But see Tollett v. Henderson, 4II U.S. 258, 267 (I973) (a defendant "may . . . attack the voluntary and intelligent character of the guilty plea by showing that the advice he received from counsel was not within the standards set forth in McMann").

${ }^{59}$ See, e.g., Tollett v. Henderson, 4II U.S. 258, 267-68 (1973); McMann v. Richardson, 397 U.S. 759, 770-71 (1970).

${ }^{60}$ See, e.g., Wainwright v. Sykes, 433 U.S. 72, 96 (r977) (Stevens, J., concurring) ("The record persuades me that competent trial counsel could well have made a deliberate decision not to object to the admission of the respondent's in-custody statement.").

61 It is doubtful that many persons convicted of a crime are aware of the avail- 
sources to maintain such an action, the obstacles to success are formidable. It is true that the elements of a legal malpractice claim are no different than those for other professional malpractice actions. ${ }^{62}$ However, establishing these elements poses a series of problems unique to legal malpractice suits.

To prove a breach of duty by his former lawyer, the client must retry the underlying litigation. ${ }^{63}$ This "suit within a suit" brings with it many of the difficulties and diseconomies of other kinds of after-the-fact scrutiny. ${ }^{64}$ Also, where the underlying trial was a civil action, the boundary between competence and incompetence is even more difficult to define than in criminal cases. ${ }^{65}$ Unlike criminal defense, there are no generally accepted professional standards that prescribe the course of civil litigation. ${ }^{66}$ Every tactical and strategic decision is a matter of the economics of the case and its peculiar facts. As a result, published successful malpractice cases have involved, almost without exception, instances of procedural

ability of malpractice actions against their former defenders, given "[t]he dearth of criminal malpractice litigation." Kaus \& Mallen, The Misguiding Hand of Counsel - Reflections on "Criminal Malpractice," 2 I U.C.L.A. L. ReV. Irgr, II93 (1974). Until the recent case of Geddie v. St. Paul Fire \& Marine Ins. Co., 354 So. 2d 718 (La. App.), writ denied, 356 So. $2 \mathrm{~d}$ Iorr (La. I978), none of the handful of reported malpractice actions arising out of criminal litigation had resulted in judgment for the plaintiff clients. See generally Annot., 53 A.L.R.3d 73I (I973).

${ }^{62}$ See, e.g., Budd v. Nixen, 6 Cal. $3^{d} 195,200,49$ I P.2d 433, 436, 98 Cal. Rptr. 849,852 (1971):

The elements of a cause of action in tort for professional negligence are: $(x)$ the duty of the professional to use such skill, prudence, and diligence as other members of his profession commonly possess and exercise; (2) a breach of that duty; (3) a proximate causal connection between the negligent conduct and the resulting injury; and (4) actual loss or damage resulting from the professional's negligence.

See also RESTATEMENT (SECOND) OF TORTS § 299A (I965). Whether this standard. makes sufficient allowance for the economic and time pressures under which lawyers must conduct litigation is open to question.

${ }^{63}$ See, e.g., Woodruff v. Tomlin, 423 F. Supp. 1284, 1288 (W.D. Tenn. 1976), rev'd on other grounds, 593 F.2d 33 (6th Cir. 1979); Campbell v. Magana, I84 Cal. App. 2d 751, 754-55, 8 Cal. Rptr. 32, 33-34 (1960). See also Coggin, Attomey Negligence . . . A Suit Within a Suit, 60 W. VA. L. Rev. 225 (1958).

${ }^{64}$ See pp. $642-46$ supra. It is true, of course, that the malpractice trial is not confined solely to the record of the underlying litigation. For example, any available witnesses may be called, and the successful malpractice plaintiff must not only establish that errors were made, but also project what the outcome and award would have been if there had been no negligence. See pp. 648-49 \& notes 69-72 infra.

${ }^{65}$ On the difficulty of defining the boundary in criminal cases, see p. 643 supra.

${ }^{66}$ See ABA Standards Relating to the Administration of Criminal JusTICE, The Defense Function (I974) [hereinafter cited as The Defense FuncTION]. 


\section{default ${ }^{67}$ or failure to do even the most cursory legal re- search. 68}

Often the hardest problem is establishing that the client was damaged by counsel's incompetence. In civil cases it is well-settled that the client must prove that a more favorable outcome would have resulted but for his attorney's incompetence, proof that will often be speculative at best. ${ }^{69}$ The outcome of any action is subject to so many uncertainties that the causal role of counsel may defy proof. This problem becomes even more complex when the client's contributory neg-

67 The following procedural defaults are typical of those which supply valid causes of action in malpractice suits: (I) failing to file suit before a statutory limitation period ran, see, e.g., Williams v. Bashman, 457 F. Supp. 322 (E.D. Pa. 1978); (2) failure to prosecute, see, e.g., Kessler v. Gray, 77 Cal. App. 3d 284, 143 Cal. Rptr. 496 (1978); (3) failure to appear, see, e.g., Warwick, Paul \& Warwick v. Dotter, Igo So. 2d 596 (Fla. Dist. Ct. App. Ig66); (4) failure to perfect an appeal, see, e.g., Welder v. Mercer, 247 Ark. 999, 448 S.W.2d 952 (1970); (5) suing the wrong party, see, e.g., Sikora v. Steinberg, 40 Misc. 2d 649, 243 N.Y.S.2d 766 (Sup. Ct. 1963); (6) failure to pursue timely discovery, assert available defenses, and appear in court, see, e.g., Public Taxi Serv., Inc. v. Barrett, 44 IIl. App. 3d 452, 357 N.E.2d r232 (1976). See also Gates \& Zilly, Legal Malpractice, in AMERICAN BaR Association, Professional ReSPoNSIBILITY 3Ir, 319-22 (1978); Leavitt, The Attorney as Defendant, 13 HASTINGS L.J. 1, 28-32 (1961); Note, Attorney Malpractice, 63 CoLUM. L. ReV. 1292, 1295-96, I298-301 (I963); Note, Liability of an Attorney in the Conduct of Litigation, 12 SYRACUSE L. REV. 494 (Ig6r).

${ }^{68}$ See, e.g., Smith v. Lewis, I3 Cal. 3d 349, 530 P.2d 589, I18 Cal. Rptr. 62 I (1975). In Smith, the California Supreme Court affirmed a jury verdict against an attorney who failed in a divorce action to assert his client's community property interest in her husband's retirement benefits. Although such rights had not yet been held by a court to be community property, the court concluded that the omission even to assert the claim implied a failure to conduct "minimal research into either hornbook or case law." Id. at 360,530 P.2d at 596, II8 Cal. Rptr. at 628. See also Ramp v. St. Paul Fire \& Marine Ins. Co., 254 So. 2d 79 (La. App. I97I) (attorneys were held liable for recommending a settlement, in a succession proceeding, for a small fraction of the clients' claim when basic knowledge of estate law would have revealed that the claim was entirely valid), modified on other grounds, 263 La. 774,269 So. 2 d 239 (1972).

A Los Angeles Superior Court judge was recently reported to have upheld a $\$ 400,000$ jury verdict returned against a lawyer who had negligently failed to pursue a product liability claim against the manufacturer of a defective punch press that cut off its operator's right index finger. Instead the lawyer had obtained a workers' compensation award of about $\$ 6,500$. NAT'L L.J., Aug. 20, 1979, at 4 , col. I.

${ }^{69}$ See, e.g., Kilmer v. Carter, 274 Cal. App. 2d 81, 78 Cal. Rptr. 800 (1969); Annot., 45 A.L.R.2d 5, 19-21 (1956). In Kilmer, judgment for the defendant attorney was affirmed, despite his negligent failure to file an appellate brief, because the client, having failed to produce evidence of the probable outcome of a retrial, had not proved he would have prevailed on appeal. The court of appeals in the malpractice action concluded that if the appeal had been prosecuted, at best a retrial on the issue of damage would have resulted. See also Woodruff v. Tomlin, 423 F. Supp. 1284, I288 (W.D. Tenn. 1976), rev'd on other grounds, 593 F.2d 33 (6th Cir. I979). 
ligence ${ }^{70}$ or failure to mitigate damages ${ }^{71}$ are issues in the malpractice action. And even when it is clear that the outcome of a case would have been different if it were not for the lawyer's incompetence, determining the dollar amount of damages is frequently very difficult. ${ }^{72}$

Thus, a legal malpractice action is an inadequate remedy for counsel's incompetence in a civil case. It is, moreover, a patently insufficient remedy for counsel's incompetence in the criminal context. Damages can hardly compensate a criminal defendant for the taint of a conviction and incarceration.

\section{GUIDELINES FOR INTERVENTION}

The trial judge therefore has a responsibility, grounded on and tempered by the adversary process and constitutional principles and reinforced by the absence of adequate alternatives, to ensure a fair trial by maintaining minimum standards of performance by counsel. ${ }^{73}$ But the judge must wield the correlative power with caution lest its exercise defeat its purpose: fairness in the administration of justice.

Assessment of an attorney's performance involves compar-

${ }^{70}$ See, e.g., Theobald v. Byers, I93 Cal. App. 2d I47, I3 Cal. Rptr. 864 (I96r); Corceller v. Brooks, 347 So. 2d 274 (La. App.), cert. denied, 350 So. 2d 1223 (La. 1977).

${ }^{71}$ See, e.g., Martin v. Hall, 20 Cal. App. 3d 414, 428, 97 Cal. Rptr. 730, 739 (197I) (where the client failed to appear at his criminal sentencing hearing, and a plea bargain was rejected by the trial judge, evidence of what the judge would have done if the client had appeared should have been admitted in the malpractice trial on the issue of damages). See also Theobald v. Byers, $193 \mathrm{Cal}$. App. 2d I47, I53, I3 Cal. Rptr. 864, 867 (r96r).

72 See, e.g., Pete v. Henderson, I24 Cal. App. $2 \mathrm{~d} 487,269$ P.2d 78 (1954). See also Kilmer v. Carter, 274 Cal. App. 2d 81, 78 Cal. Rptr. 800 (I969); Annot., 45 A.L.R.2d 62 (I956); note 69 supra.

Complexities are inherent both in determining how much lighter a sentence would have resulted but for the criminal defense lawyer's negligence, and in evaluating the damages for any time unnecessarily served. See Geddie v. St. Paul Fire \& Marine Ins. Co., 354 So. 2d 718 (La. Ct. App.), cert. denied, 356 So. 2d IoII (La. 1978). Geddie affirmed a finding that the defendant criminal defense attorney's negligence in failing to raise a double jeopardy defense resulted in eight months of illegal confinement of the plaintiff. The trial judge's award of $\$ 7,000$ per month, based on the plaintiff's imprisonment at the state penitentiary, was reduced by the court of appeals to $\$ 1,500$ per month because, but for the plaintiff's own misconduct, he would have spent the time at a minimum security facility.

${ }^{73}$ See Glasser v. United States, 315 U.S. 6o, 7I (1942) ("Upon the trial judge rests the duty of seeing that the trial is conducted with solicitude for the essential rights of the accused."); Powell v. Alabama, 287 U.S. 45, 52 (I932) ("It' was the duty of the court having [defendants'] cases in charge to see that they were denied no necessary incident of a fair trial."); notes 26-27 supra. See generally Comment, Incompetency of Counsel, 25 BAYLOR L. REv. 299 (1973). 
ison with other performances ranging over a broad spectrum of skill, experience and diligence. It is influenced by the observer's perspective and his knowledge of the facts and circumstances of the case. Without that knowledge, not usually fully accessible to the trial judge, litigation strategy is difficult to evaluate. Evaluation, moreover, must eschew the trial judge's idealized conception of how he would have tried the case in favor of what could reasonably be expected. ${ }^{74}$ The trial judge's discretion, consequently, must be guided by an awareness that the assertion of judicial power can have serious consequences for the independence of counsel, the integrity of the attorney-client relationship, and the proper functioning of the adversary process. Yet caution must not deter action where judicial passivity would invite injustice. When there is a need to exercise judicial power, the fear of abuse should not be a ground for accepting the evils at which the power is aimed.

In presiding over any trial, the judge seeks to achieve fairness. ${ }^{75}$ Where the law affords him discretion in the application of substantive or procedural rules, fairness normally will guide its exercise. Since the competence of counsel is an element of a fair trial, achieving fairness will require the monitoring of counsel's performance and intervention in appropriate circumstances. This does not require the judge to evaluate the relative efficacy of trial tactics or to determine whether counsel's performance should receive a passing grade. Nor is the trial judge called upon to rule whether counsel's performance satisfies one of the minimum standards formulated by the appellate courts or whether a party is being denied effective representation. Instead, his function is to remedy observed deficiencies before it is too late, resorting always to the least intrusive measure adequate to the need.

Nevertheless, the decisions of appellate courts in cases of alleged incompetence of counsel are relevant to the present analysis. They illuminate the scope of defendants' rights and the areas where incompetence of counsel, if left unremedied,

${ }^{74}$ See the discussion at pp. 642-46 supra. See also Moore v. United States, 432 F.2d 730 (3d Cir. I970), where the court described some of these difficulties as follows:

The artistry of the advocate is difficult to judge retrospectively because the elements influencing judgment usually cannot be captured on the record. The kaleidoscopic range of possibilities often seems limitless, and it is proverbial that the finest ideas emerge on the way back from the courthouse. The advocate's work, therefore, is not readily capable of later audit like a bookkeeper's.

Id. at 736-37.

${ }^{75} \mathrm{See}$ note 73 supra. 
may lead to reversible error. The purpose of this discussion, however, is not to help trial judges avoid reversals as much as to serve as a guide to judicial monitoring and intervention to the end that lawyer incompetence will not be permitted to impair the fairness of the judicial process.

\section{A. In the Criminal Process}

I. Pretrial Phase. - The trial judge's concern with the effectiveness of the assistance of counsel begins with the appointment of counsel. Defendants lacking the resources to retain counsel are constitutionally entitled to appointed counsel. ${ }^{76}$ The appointment must be made sufficiently in advance of trial to allow counsel a reasonable time for preparation or the trial must be continued. ${ }^{77}$ The judge should make an independent judgment whether there is sufficient time to prepare, for either counsel or the defendant may, for reasons of their own, fail to request a continuance even where one is needed. ${ }^{78}$ Finally the judge should consider objections to the appointed counsel made by the defendant and satisfy himself of the competence of the attorney being appointed. ${ }^{79}$

Once counsel has appeared or has been appointed, the judge must not tolerate procedural or structural impediments to effective assistance. The defendant must be given adequate opportunity to consult with counsel in private, and to have counsel present at every "critical stage in a criminal proceeding," 80 including the preliminary hearing, the arraignment, and any lineup for identification. ${ }^{81}$

${ }^{76}$ See Argersinger v. Hamlin, 407 U.S. 25 (I972); Gideon v. Wainwright, 372 U.S. 335 ( 1963 ); notes $32-33$ supra.

77 See MacKenna v. Ellis, 280 F.2d 592 (5th Cir. r960); $c f$. Chambers v. Maroney, 399 U.S. 42, 54 (I970) (courts should make an effort to effect early appointment of counsel, although late appointment does not require an evidentiary hearing on denial of sixth amendment rights); $i d$. at 55-60 (Harlan, J., concurring and dissenting) (hearing required on adequacy of representation by counsel entering case at last minute). See also Moore v. United States, 432 F.2d 730 (3d Cir. . 1970) (where defendant is represented by a defender organization, the relevant time is the appointment of the organization, not the assignment of a particular attorney).

${ }^{78}$ See United States ex rel. Williams v. Twomey, 510 F.2d 634 (7th Cir.) (defendant failed to request continuance of trial; had he done so, under Illinois statute he could have been subject to an additional four months of pretrial incarceration), cert. denied, 423 U.S. 876 (1975).

${ }^{79}$ See MacKenna v. Ellis, 280 F.2d 592 (5th Cir. 1960) (court appointed, over defendant's objection, two newly admitted lawyers whose subsequent performance turned out to be ineffective).

${ }^{80}$ Hamilton v. Alabama, 368 U.S. 52, 53 (I96I).

81 See Coleman v. Alabama, 399 U.S. I (I970) (preliminary hearing); United States v. Wade, 388 U.S. 2 I8 ( 1967 ) (pretrial identification lineup); Hamilton v. Alabama, 
If at any time during the proceeding the defendant makes a seemingly substantial complaint about the adequacy of counsel, whether appointed or retained, the judge should conduct an inquiry and make findings on whether bona fide grounds exist for a change of counsel. ${ }^{82}$ A unilateral dismissal of coun- sel by the defendant cannot be taken as a surrender of the right to counsel; the court must conduct an inquiry to determine whether a waiver was intended..$^{83} \mathrm{~A}$ defendant's choice to proceed without counsel confronts the court with the difficult problem of determining whether the waiver was knowing and voluntary. ${ }^{84}$ Searching inquiry into the defendant's understanding of the direct and potential consequences of the choice must be pursued. ${ }^{85}$ Even if the defendant's choice is accepted, however, the court should appoint advisory counsel to assist both defendant and the court. ${ }^{86}$ Advisory counsel

368 U.S. 52 ( $196 \mathrm{I}$ ) (arraignment); United States v. Smith, 4II F.2d 733 (6th Cir. r969) (return of verdict and poll of jury). See generally Herring v. New York, 422 U.S. 853, 857 (1975); see also notes 35-37 supra.

82 See United States v. Woods, 487 F.2d 1218 (5th Cir. 1973); United States v. Young, 482 F.2d 993 (5th Cir. 1973); United States v. Morissey, 461 F.2d 666 (2d Cir. I972); United States v. Calabro, 467 F.2d 973 (2d Cir. 1972), cert. denied, 410 U.S. 926 (1973); Brown v. Craven, 424 F.2d II66 (gth Cir. I970); People v. Marsden, 2 Cal. 3d rr8, 465 P.2d 44, 84 Cal. Rptr. I56 (1970).

Although the defendant is more likely to express dissatisfaction with appointed than with retained counsel, there is no persuasive reason for the judge to make distinctions between the two in dealing with incompetence. See McQueen v. Swenson, 498 F.2d 207, 217 n.14 (8th Cir. I974); United States v. Marshall, 488 F.2d Ir69, II92-93 (9th Cir. I973); Monroe v. United States, 389 A.2d 811, 820 (D.C.), cerl. denied, 439 U.S. 1006 ( 1978 ). Analytically, the distinction may be relevant to the issue whether there has been a "denial" of effective assistance, see Comment, supra note 73 , at $308-16$, but not to the trial judge's concern with a fair trial, see note 73 supra.

${ }^{83}$ See Sawicki v. Johnson, 475 F.2d 183 (6th Cir. I973).

84 Other potential problems that might flow from the recognition of a constitutional right to self-representation are suggested in Justice Blackmun's dissenting opinion in Faretta v. California, 422 U.S. 806, 852 (r975).

${ }^{85}$ See People v. Medina, 44 N.Y.2d 199, 207, 375 N.E.2d 768, 772 (1978). See also TRIAL JUDGE, supra note $23, \S 6.6$, at $180-8 \mathrm{r}$ :

A defendant should be permitted at his election to proceed in the trial of his case without the assistance of counsel only after the trial judge makes thorough inquiry and is satisfied that he (i) has been clearly advised of his right to the assistance of counsel, including his right to the assignment of counsel when he is so entitled; (ii) possesses the intelligence and capacity to appreciate the consequences of this decision; and (iii) comprehends the nature of the charges and proceedings, the range of permissible punishments, and any additional facts essential to a broad understanding of the case.

${ }^{86}$ See TRIAL JUDGE, supra note 23 , § 6.7; $c f$. Faretta v. California, 422 U.S. 806, $834 \& \mathrm{n.46}$ (I975) (state may appoint advisory counsel to assist defendant if requested, even over objection of the accused). The Court also observed that "the trial judge may terminate self-representation by a defendant who deliberately engages in serious and obstructionist misconduct." Id. 
might well be directed to consult with the defendant before the court decides whether to permit him to proceed pro se.

Joint representation by counsel of two or more defendants having actual or potential conflicting interests may deprive one or more of them of effective assistance. ${ }^{87}$ Defendants may waive the right to separate representation free of conflict, but a waiver will neither be presumed nor found lightly. ${ }^{88} \mathrm{Al}-$ though courts have taken different views concerning the duty of the trial court to act on its own initiative to deal with apparent conflicts, ${ }^{89}$ it is clear the court must be alert to the possibility of conflict. When a possible conflict is indicated, the court must either conduct an inquiry, to the extent it can do so consistent with counsel's duty of confidentiality to his client, or simply appoint separate counsel. ${ }^{90}$ When the judge

${ }^{87}$ See note 39 supra; DefENSE Function, supra note $66, \S 3.5$.

${ }^{88}$ See Glasser v. United States, 315 U.S. 60, 70 (1942) (court will "indulge every reasonable presumption against the waiver" of right to counsel); United States v. Bernstein, 533 F.2d 775, 787-89 (2d Cir.) (waiver rejected where defendant found to be frightened of trial and of new counsel), cert. denied, 429 U.S. 998 (1976); United States v. Garcia, 517 F.2d 272 (5th Cir. 1975) (waiver of right to counsel free of conflict of interest permissible where defendant's voluntariness and knowledge of consequences are manifest on face of record).

89 In Foxworth v. Wainwright, 516 F.2d 1072, 1076 (5th Cir. 1975), the court held that "the trial judge has an obligation . . . to anticipate conflicts reasonably foreseeable at the outset of the case, when counsel is appointed." Appointed counsel's joint representation of the petitioner and two codefendants on a murder charge arising out of the beating of a cellmate in a reformatory was held to have denied the petitioner effective assistance of counsel because counsel was precluded from choosing to further the petitioner's defense by establishing that another codefendant was the sole participant in the homicide. See also MacKenna v. Ellis, 280 F.2d 592 (5th Cir. 1960) (appointed defense counsel who had pending applications for positions with the prosecuting attorney's office did not satisfy sixth amendment requirement), modified, 289 F.2d 928 (5th Cir. I96r); TrIaL JUDGE, supra note $23, \S 3.4$ (b) (suggesting that the judge should inquire into potential conflicts whenever two or more jointly charged defendants are represented by the same attorney). Other courts have held that the trial judge must inquire into possible conflicts only after indicia or suggestions of conflict have appeared. See United States v. Lawriw, 568 F.2d 98, I02-03 (8th Cir. I977), cert. denied, 435 U.S. 969 (1978).

${ }_{90}$ See Holloway v. Arkansas, 435 U.S. 475, 484-86 (I978); United States v. Vargas-Martinez, ${ }_{56}$ F.2d 1102 (9th Cir. 1978); Abraham v. United States, 549 F.2d 236 (2d Cir. 1977); United States v. Carrigan, 543 F.2d I053 (2d Cir. 1976); United States v. DeBerry, 487 F.2d 448 (2d Cir. x973); United States v. Sheiner, 4Io F.2d 337, 342 (2d Cir.), cert. denied, 396 U.S. 859 (I969).

The difficulties inherent in determining whether the defendants have made an informed and voluntary decision to accept joint representation are discussed in United States v. Garafola, 428 F. Supp. 620 (D.N.J. 1977), aff'd sub nom. United States v. Dolan, 570 F.2d II 77 (3d Cir. I978). The judge is hampered here by his lack of knowledge of the case and by the restraints imposed by the fifth and sixth amendments and rules of confidentiality. The defendants, moreover, will presumably have already been advised by their counsel that no conflict exists. See also United States v. Partin, 
perceives the possibility of a conflict, he ought not to ignore the problem simply on the strength of counsel's failure to raise it, for the source of the conflict, joint representation, may be the cause of counsel's silence. ${ }^{91}$

2. Monitoring Trial Preparation. - Adequate preparation lies at the heart of a competent trial performance. ${ }^{92}$ It is far preferable for the judge to monitor the adequacy of preparation before the trial begins than to wait until trial when remedial action becomes more difficult. ${ }^{93}$ Unfortunately, there are no general and objective standards by which to test the adequacy of counsel's preparation; it turns on the circumstances of each case, the information received by counsel from defendant, the opportunities for making a defense, and the tactical choices mandated by the client's interests.

A starting point may nevertheless be found in the American Bar Association's Standards for the Defense Function, ${ }^{94}$ specifying that to be adequately prepared counsel should

(I) Confer promptly with the client, discuss all aspects of the case fully and seek to determine all relevant facts; ${ }^{95}$

(2) Advise the client promptly of any possible conflict of interest; 96

(3) Inform the client promptly of his rights and all possible defenses and take steps to vindicate those rights; ${ }^{97}$

(4) Conduct a prompt investigation of the circumstances of the case, including the information in the possession of the prosecution; ${ }^{98}$ and

6or F.2d 1000 (9th Cir. 1979); Willis v. United States, No. 78-2361 (9th Cir. Nov. 5 , I979).

91 Indicia of potential conflict exist where one defendant might later decide to testify and cross-examination on behalf of the other might become necessary, where one defendant is charged with a substantive offense and conspiracy and a codefendant with conspiracy only, where the degree of active participation in the offense appears to differ between defendants, where by reason of age differences or family relationship one defendant may be in a dominant position over the other, where the circumstances suggest the availability of a defense to one defendant but not the other, or where counsel is paid by only one of the defendants. See United States v. Marshall, 488 F.2d II69, I190-94 (9th Cir. 1973).

92 The responses of $I, 422$ judges to the American Bar Foundation's survey indicated that the dominant factor determining competence was preparation, followed by experience and training, presentation, and personal conduct and appearance. See Maddi, supra note 7 , at 124 .

${ }_{93}$ See Monroe v. United States, 389 A.2d 8I I, 818-19 (D.C.), cert. denied, 439 U.S. 1006 (I978); pp. 660-6r infra.

94 The Defense Function, supra note 66.

${ }^{95}$ See The Defense Function, supra note $66, \S 3.2(\mathrm{a})$.

${ }^{96}$ See id. \$ 3.5(a).

97 See id. \$ 3.6(a).

${ }^{98}$ See id. § 4.I. 
(5) Advise the client fairly and fully concerning all aspects of the case. ${ }^{99}$

Reference to these standards alone, of course, will not assure the court that what counsel has done was adequate, correct and fair. But they do provide a checklist for use at appropriate points in the pretrial process when symptoms of incompetence, such as lack of preparation, indicate the need for inquiry.

An effective vehicle for pretrial monitoring of counsel's competence is the pretrial conference. ${ }^{100}$ Even if brief, such a conference will compel counsel to focus attention on the trial, inform them of their obligations, and disclose evident deficiencies. An agenda would include items such as the following:

(I) Defining what, under the statute charged, are the precise legal and factual issues to be tried and what subsidiary issues are in dispute, such as identification, ownership, chain of custody or the chemical composition of relevant substances;

(2) Summarizing the prosecution's testimonial and documentary evidence, including what witnesses will be called and what documents and other materials offered;

(3) Reporting on the status of discovery, including the production of exculpatory materials and other information in the prosecution's possession to which the defense may be entitled;

(4) Exploring any potential evidentiary problems, including possible grounds for the suppression or exclusion of certain evidence, application of the confrontation clause, and limitations on the use of prior convictions; and

(5) Considering possible defenses, such as alibi and entrapment (including the availability of supporting witnesses), and available pretrial motions (such as for severance of defendants or counts).

Participation in a conference based on such an agenda will almost certainly make defense counsel conscious of any gaps in his preparation. The judge in turn will be able to get a sense of the extent of counsel's preparation, familiarity with

${ }^{99}$ See id. § 5.I.

100 See generally ABA STANDARDS RELATING To the AdMinistration of CrimINAL JUStice, Discovery AND Procedure Before TrIal §§ I.4, 5.3, 5.4 (I974); TRIAL JUDGE, supra note $23, \S 3.6$.

The court should also consider the pleadings and courtroom performance of counsel in connection with motions and other pretrial appearances to monitor the adequacy of his knowledge of relevant law and procedural rules and mastery of the facts of the case, as well as his capacity to argue in a cogent manner. 
criminal trial procedure, and general competence to handle the defense. Serious deficiencies are likely to be disclosed at such a conference, affording the trial judge an opportunity to take preventive action.

Pretrial monitoring will enable the judge to measure the adequacy of counsel's preparation for trial against minimal standards of preparedness. For example, counsel cannot render effective assistance without having made an adequate investigation. ${ }^{101}$ While he has no duty to manufacture a false defense, ${ }^{102}$ or to undertake a dragnet search simply in the hope of turning up helpful evidence, ${ }^{103}$ he must at least interview eyewitnesses and pursue other evident leads that may provide support for clearly indicated defenses. Only after such an investigation can he advise his client properly and make the required tactical decisions. If counsel's performance at the pretrial conference suggests a serious lack of preparation, the judge might well make discreet inquiries, short of asking the defense to disclose its case, whether, for example, eyewitnesses or alibi witnesses have been interviewed and are likely to be called and about what plans exist to produce other witnesses or exhibits to support particular defense theories. ${ }^{104}$

One aspect of counsel's preparation is obtaining exculpatory and other helpful information in the prosecution's possession to which the defendant may by law be entitled. Under Brady $v$. Maryland,${ }^{105}$ the government has a duty to turn over to the defendant without request only material which is "highly probative of innocence,"106 that is, evidence the withholding of which would deprive the defendant of a fair trial. The prosecution may, however, have other materials of potential, if lesser, help to the defendant which it must turn over only if

${ }^{101}$ See McQueen v. Swenson, 498 F.2d 207 (8th Cir. 1974); 560 F.2d 959 (8th Cir. 1977) (where murder defendant claimed self-defense, defense counsel held ineffective, having failed to interview any of prosecution's $4 \mathrm{I}$ listed and 26 called witnesses, to obtain weapon allegedly used by the deceased assailant, and to seek information from other sources). See also Coles v. Peyton, 389 F.2d 224 (4th Cir. 1968) (in rape prosecution, defense counsel held ineffective, having failed to interview any of the known eyewitnesses and to inform defendant of the elements of the charged offense); Brubaker v. Dickson, 3ro F.2d 30 (9th Cir. 1962) (failure to contact obvious witnesses and assert obvious defenses).

102 See Matthews v. United States, 518 F.2d I245 (7th Cir. 1975).

${ }^{103}$ See Jackson v. Cox, 435 F.2d ro89 (4th Cir. 1970).

${ }^{104}$ Requiring counsel to conduct an adequate pretrial investigation does not mean that it must be personally performed by the attorney. The Criminal Justice Act, 18 U.S.C. $\$ 3006 \mathrm{~A}(\mathrm{e})$ (1976), for example, authorizes the payment of reasonable amounts, on counsel's application, for investigator's services.

${ }^{105} 373$ U.S. 83 (1963).

106 United States v. Agurs, 427 U.S. 97, I I0 (1976). 
requested to do so. ${ }^{107}$. A failure to make appropriate requests may be another danger signal.

Along with investigating the facts, counsel preparing for trial must review the defenses and objections available to the defendant and consider whether and how they are to be raised. The fourth, fifth, and sixth amendments afford a defendant a spectrum of rights ranging from those not subject to waiver to those that are lost if not asserted at the first opportunity. The judge during the pretrial phase must be alert to the protection of these rights by counsel and to the possible need for judicial intervention.

Certain rights may not be waived. For example, due process categorically precludes the trial of any legally incompetent defendant. Regardless of whether counsel raises the issue, therefore, the judge must conduct a hearing whenever circumstances create a bona fide doubt as to defendant's competence. ${ }^{108}$ Other rights and objections, however, are generally subject to loss by waiver. Certain of those rights, such as the rights to a trial on the charges, to a jury, and to the assistance of counsel, are considered to be so substantial that they can be surrendered only by a knowing and voluntary waiver by the defendant. The judge has a duty to conduct a hearing to satisfy himself, regardless of the representations of counsel, that the waiver is the product of the defendant's decision, reached on the basis of competent legal advice. ${ }^{109}$

The largest category of rights consists of "trial-type" rights which, although regarded as substantial, are subject to waiver by the act or omission of counsel. ${ }^{110}$ Their assertion turns on tactical decisions "in which the expertise of counsel [is] significant and the defendant's feelings on the matter insignificant." 111 Their loss through counsel's action or inaction, is, in the absence of "plain error," not reviewable. ${ }^{112}$ If

107 See id. (where murder defendant claimed self-defense, it was not error for prosecution not to produce victim's arrest record without request).

${ }^{108}$ See Drope v. Missouri, 420 U.S. 162, I8I (I975); Pate v. Robinson, 383 U.S. 375,385 (I966); de Kaplany v. Enomoto, 540 F.2d 975, 979-83 (9th Cir. 1976) (en banc), cert. denied, 429 U.S. I075 (1977).

${ }^{109}$ See Johnson v. Zerbst, 304 U.S. $45^{8}$ (I939); TrLal JudGe, supra note 23, $\S \S 3,4,4.3,6.6$ ("a defendant's plea of guilty based on reasonably competent advice is an intelligent plea not open to attack on the ground that counsel may have misjudged the admissibility of the defendant's confession"). See also Tollett v. Henderson, 4II U.S. 258 (I973); McMann v. Richardson, 397 U.S. 759, 770-7I (1970).

110 See Estelle v. Williams, 425 U.S. 50r, 5 I4 n.4 (I976) (Poweli, J., concurring); Wainwright v. Sykes, 433 U.S. 72, 92-94 (I977) (Burger, C.J., concurring). See also THE DEFENSE Function, supra note $66, \S 5.2$.

111 United States ex rel. Green v. Rundle, $45^{2}$ F.2d 232 (3d Cir. I97I).

112 See Francis v. Henderson, 425 U.S. 536 (I976) (failure to object to unconsti- 
these kinds of rights are not to be forfeited through incompetence of counsel, the trial judge must be prepared to intervene. ${ }^{113}$

Perhaps the most common situation implicating the last category of rights involves the use of evidence which may be subject to suppression because illegally obtained. The judge must begin with the assumption that defense counsel, if competent and prepared, is in the best position to make the tactical decision whether to make the motion. Even when good grounds exist, counsel's judgment may lead him to waive an objection where, for example, he considers the evidence to be on balance more exculpatory than incriminatory. ${ }^{114}$ Nevertheless, courts have recognized "alerting circumstances" which obligate the trial judge to investigate the need for a suppression hearing. Such circumstances may exist where there is a serious doubt about the voluntariness of a confession, as, for example, where the defendant displays an abnormal mental or physical condition or obvious ignorance or lack of awareness. ${ }^{115}$

Similar alerting circumstances should lead the judge to question counsel when a significant default appears imminent, such as a failure to challenge obvious racial bias in the makeup of a grand or petit jury, ${ }^{116}$ or to attack a prejudicial misjoinder of counts or defendants which could result in the admission of otherwise inadmissible evidence or keep a defendant off the witness stand under circumstances likely to result in prejudice. ${ }^{117}$

tutional grand jury selection); Estelle v. Williams, 425 U.S. 50r (1976) (failure to object to defendant's appearance at trial in prison clothes); Davis v. United States, 4II U.S. 233 (I973) (failure to object to unconstitutional jury selection); note 5 I supra. 113 See note 52 supra.

${ }^{114}$ See Wainwright v. Sykes, 433 U.S. 72, 96-97 (1977) (Stevens, J., concurring); United States v. Powe, 59I F.2d 833, 842 \& n.29 (D.C. Cir. 1978).

${ }^{115}$ See United States v. Powe, 59I F.2d 833, 842-44 (D.C. Cir. 1978) (unpreparedness of counsel on issue of admissibility of confession and evidence of direct or implied promises of leniency raised doubt as to voluntariness of confession); United States v. Taylor, 374 F.2d 753, 756 (7th Cir. I967) ("a defendant's apparent abnormal mental or physical condition, obvious ignorance, or lack of awareness" may raise doubt as to voluntariness of confession); $c f$. LaFrance v. Bohlinger, 499 F.2d 29, 35 (Ist Cir.) (indications of threats or duress by police require hearing on voluntariness), cert. denied, 4I9 U.S. I080 (1974); Grieco v. United States, 435 F.2d 677, 678 (7th Cir. 1970) (special circumstances may justify sua sponte hearing on voluntariness), cert. denied, 401 U.S. 1009 (1971); Jacobson v. California, 43r F.2d ror7, 1019 (gth Cir. 1970) (absent objection or evidence of involuntariness, no need for a special hearing).

${ }^{116}$ See Lee v. Hopper, 499 F.2d 456, 464-65 (5th Cir.), cert. denied, 419 U.S. I053 (1974).

117 See United States ex rel. Green v. Rundle, 452 F.2d 232 (3d Cir. 197I); Trial JUDGE, supra note $23, \S 3.9$ (suggesting the judge order severance sua sponte where appropriate). 
3. Pretrial Intervention. - A range of options is available to the court at the pretrial stage should it decide intervention is necessary. When inquiry discloses that counsel appears to be lacking in diligence or skill, but the shortcomings appear to be remediable, the court should consider giving appropriate suggestions, advice or directions to prevent a default, preferably on the record and in the presence of opposing counsel. In case of a serious deficiency, the judge may well admonish or rebuke counsel. ${ }^{118}$ But where counsel's inadequacy appears to be so serious that it creates a risk of ineffective representation, the court should advise the client of that fact and of the right to change counsel. If the client declines the advice, the court may require the association of qualified trial counsel or himself appoint advisory counsel to assist the defense. ${ }^{119}$

Even where the defendant does not consent, the court may, where gross incompetence has been demonstrated, bar counsel and appoint substitute counsel or require defendant to proceed with different retained counsel. The defendant's right to "obtain private counsel of his own choice . . . must be weighed and balanced against an equally desirable public need for the efficient and effective administration of criminal justice." 120 Accordingly, courts have appointed substitute counsel or required a defendant unwilling to retain or accept appointed substitute counsel to proceed pro se where counsel had to be barred for disruptive behavior, had been continuously unavailable, or had a conflict of interest. ${ }^{121}$ In the recent case

118 The American Bar Foundation survey found that more than $96 \%$ of the judges responding had at some time dealt with incompetence by giving "instruction or advice" in chambers, $77 \%$ had "rebuked" counsel in chambers, and a majority had given "instruction or advice" in open court. Maddi, supra note 7, at I29.

${ }^{119}$ Cf. United States v. Bubar, 567 F.2d I92, 203-04 (2d Cir.) (appointed attorney believed by court to be more effective than retained counsel participated in defense with court's permission), cert. denied, 434 U.S. 872 (I977).

120 United States ex rel. Carey v. Rundle, 409 F.2d I210, I2I4 (3d Cir. 1969), cert. denied, 397 U.S. 946 (1970) (defendant's delay in obtaining own counsel).

${ }^{121}$ See United States v. Vargas-Martinez, 569 F.2d I102 (9th Cir. I978) (substitution ordered of counsel for one of two defendants because common counsel had conflict); United States v. Poulack, 556 F.2d 83 (Ist Cir.) (after a prior continuance when defendant's counsel was unavailable, and after giving defendant time to retain other counsel, court appointed counsel), cert. denied, 434 U.S. 986 (I977); United States v. Dinitz, 538 F.2d I2 I4 (5th Cir. I976) (en banc) (court barred one of plaintiffs co-counsel from courtroom after repeated misconduct), cert. denied, 429 U.S. IIO4 (1977). See also United States v. Mardian, 546 F.2d 973 (D.C. Cir. 1976) (illness of counsel of choice among factors which should have caused severance of defendant's trial); United States v. Tortora, 464 F.2d I2O2, I2 Io (2d Cir.) (right to counsel not absolute and waivable if attorney not selected in reasonable time), cert. denied, 409

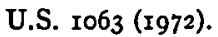

If it becomes necessary to suggest or order the removal of an attorney, the judge 
of United States $v$. Rogers, ${ }^{122}$ the district court, after declaring a mistrial, granted the government's motion to disqualify defense counsel on the ground of incompetence. Similarly, where counsel is not a member of the bar of the court, leave to appear pro hac vice may be denied or withdrawn for failure to meet minimum standards of competence or conditioned on association of qualified local counsel. ${ }^{123}$

should keep in mind the court's disciplinary authority over attorney's fees. Cases involving conflicts of interest support the discretion of trial courts to alter fee agreements and even to order the return of fees to the client in the interest of fairness. Coffelt v. Shell, 577 F.2d 30 (8th Cir. 1978); In re Fountain, 74 Cal. App. 3d 7I5, I4I Cal. Rptr. 654 (1977). Exercise of that discretion may also be appropriate where, because of counsel's incompetence, a fee agreement is unfair or where prepayment of fees could otherwise preclude the client from discharging an incompetent lawyer.

${ }^{122} 47 \mathrm{r}$ F. Supp. 847 (E.D.N.Y. 1979). On motion of the government, and over defendant's objection, the court disqualified an 83-year-old retained lawyer, stating:

Davidson's representation of his client in these proceedings falls far short of the level of competency required of criminal defense counsel. We note again his failure to pursue needed discovery; his failure timely to move for a bill of particulars, severance and change of venue; his lack of preparation for witness examination; his inability to hear the proceedings, with its consequent disruptive effect on the clear presentation of evidence; and his failure to abide by rulings of the court and inability generally to conduct himself before the jury in a manner consistent with his obligation to his client, thereby subverting the integrity of the factfinding process.

Id. at 855-56 (footnotes omitted). See also Harling v. United States, 387 A.2d Iror, IIO5 (D.C. I978) ("Gross incompetence . . . of counsel . . may justify the court's removal of an attorney, even over the defendant's objection.").

${ }^{123}$ See TRIal JUDGE, supro note $23, \$ 3.5$. Membership in the bar of a federal court is a constitutionally protected right which cannot be withdrawn without a hearing. Theard v. United States, 354 U.S. 278 (I957); Selling v. Radford, 243 U.S. 46 (IgI6). The court must therefore meet the minimal requirements of procedural due process - notice, a meaningful opportunity to be heard, and the statement of a rational basis for the decision - before excluding a member of its bar, even if it is only from participation in a particular case.

The right of a lawyer not admitted to the bar of the court to appear pro hac vice is created and defined by the law of the forum. Leis v. Flynt, 439 U.S. 438,442 (1979) (per curiam). Whether the right to appear pro hac vice can be denied or withdrawn without procedural due process depends therefore on whether the forum court's law creates a legitimate claim of entitlement "derived from statute or legal rule or through a mutually explicit understanding." Id. Ohio law, involved in the Flynt case, gave out of state lawyers no protected property right to appear pro hac vice; thus, no procedural protections needed to precede the denial of an application to appear. Id. at 443-44. The different rights that exist elsewhere, whether created by rule of court, e.g., in the Southern District of New York as interpreted by Spanos v. Skouras Theatres Corp., 364 F.2d 16I, I68 (2d Cir.) (en banc), cert. denied, 385 U.S. 987 (Ig66); but see Leis v. Flynt, 439 U.S. at 442 n.4, or by judicial decision, see, e.g., In re Evans, 524 F.2d 1004 , 1007 (5th Cir. 1975), may create claims of entitlement subject to procedural protections similar to those appropriate in a case where the attorney in question is a member of the bar of the court. But these procedural requirements can readily be satisfied where a lawyer has demonstrated incompetence sufficiently egregious to merit denial or withdrawal of permission to appear. $C f$. In re Rappaport, $55^{8}$ F.2d 87 (2d Cir. 1977) (attorney admitted pro hac vice subject to 
4. Monitoring the Trial. - Monitoring performance becomes more difficult once the trial begins and tactical decisions dominate the proceeding. The adequacy of counsel's performance must then be judged, not on the basis of isolated acts or omissions, but by its overall impact. As the trial develops, cumulative failures to participate effectively in the jury selection process ${ }^{124}$ and in the examination or cross-examination of critical witnesses ${ }^{125}$ may sooner or later warrant intervention, particularly when indicia of incompetence have appeared in pretrial proceedings. Similarly, the personal conduct of counsel may impinge on the effectiveness of the representation and call for intervention; the judge should be alert for evidence of inattention, ${ }^{126}$ apparent physical or emotional weaknesses of counsel, ${ }^{127}$ and bizarre courtroom behavior. ${ }^{128}$ Judicial tolerance or indulgence of such conduct may not be a virtue.

At the same time the judge must take care not to use his

local ethical standards and court supervision); Sanders v. Russell, 40r F.2d 24I (5th Cir. I968) (recognition of interest in maintaining high quality of representation).

${ }^{124}$ See Marzullo v. Maryland, 56r F.2d 540 (4th Cir. 1977) (failure to object to reference to prior indictment in presence of prospective jury panel, to pursue effectively question of possible jury bias, and to request cautionary instruction), cert. denied, 435 U.S. rorI (1978).

${ }^{125}$ See United States v. Clayborne, 509 F.2d 473, 484-86 (D.C. Cir. 1974) (Bazelon, J., dissenting) (failure to cross-examine effectively chief prosecution witness whose testimony was unreliable and perhaps incredible); Moore v. United States, 432 F.2d 730, 738-39 (3d Cir. I970) (en banc) (failure to cross-examine critical identification witness on previous inability to identify defendant, coupled with failure to investigate prior attempt to identify defendant at lineup and call eyewitnesses allegedly unable to identify defendant).

${ }^{126} \mathrm{See}$ United States v. Hammonds, 425 F.2d 597, 602-04 (D.C. Cir. 1970) (failure to appear at arraignment, conduct jury voir dire, make opening statement, cross-examine two of four government witnesses, request jury instructions, or make more than a perfunctory closing argument established mechanical nature of defense sufficient to prove absence of effective assistance). But see United States v. Katz, 425 F.2d 928, 93 I (2d Cir. 1970) (no reversal even though defense counsel heard to express unhappiness over having the case and was twice seen sleeping during witness examination).

${ }^{127} C f$. Butler v. United States, 260 F.2d 574 (4th Cir. I958) (per curiam) (retained counsel under indictment for drug offense and under treatment for addiction is cause for concern); Hudspeth v. McDonald, I20 F.2d 962, 966-68 (Ioth Cir.) (defense counsel alleged to have drunk excessively during trial), cert. denied, 3I4 U.S. 6I7 (r94I).

${ }_{128}$ See Beasley v. United States, 49I F.2d 687 (6th Cir. r974) (defense counsel, among other things, called obviously hostile FBI agent for no apparent purpose, waived jury although judge who would try case had received damaging inadmissible information about defendant, failed to request fingerprint report though judge had ordered government to pay for it, and failed to call res gestae witnesses unable to identify defendant).

Such behavior, as well as misconduct in general which may result from incompetence, may at some point amount to contempt, a subject beyond the scope of this Article. 
power so as to impede the effective performance of counsel. In managing the proceeding in court, he must not permit procedural rules or practices to hamper counsel unduly. ${ }^{129} \mathrm{He}$ must respect the confidentiality of counsel's communications with his client and of his work product. He needs to recognize that a lawyer's approach to a case is individualistic, that tactical judgments will vary, and that a novel strategy may be sound, particularly where the case against the defendant appears overwhelming. ${ }^{130}$

Having all of these cautions in mind, the judge nevertheless ought continuously to be conscious of threats to the fairness of the trial. His trial experience and legal knowledge should enable him to spot a problematical performance. Beyond that, he should not ignore his intuition, tutored by his observation of many lawyers, about the soundness of the performance of the lawyer before him. ${ }^{131}$

5. Intervention at Trial. - As the trial progresses, the opportunity for prophylactic action decreases while the impact of intervention may become more drastic. Judicial intervention must therefore be timely to prevent cumulative damage by incompetence, yet must be undertaken with caution in view of its likely effect on counsel's conduct of the trial and its impact on the jury. But, when intervention is necessary the range of options is generally similar to that available before trial. ${ }^{132}$

When counsel's conduct of the trial raises a question in the judge's mind concerning competence, he should raise that question with counsel at a sidebar conference or, if the matter is sufficiently serious, in chambers. He must do so promptly if damage is to be avoided. On the other hand, the judge obviously should not make it a practice to query lawyers about their conduct of the case; there must be alerting circumstances to justify the action.

${ }^{129}$ See p. 640 supra.

${ }^{130}$ See United States v. Bubar, 567 F.2d 192, 202 n.17 (2d Cir.) (quoting Judge Friendly in United States v. Katz, 425 F.2d 928, 930 (2d Cir. 1970)), cert. denied, 434 U.S. 872 (I977).

131 Although the emphasis here has been on incompetence of defense counsel, the court ought to monitor the performance of counsel for the prosecution as well, principally in the course of the trial. Manifestly ineffective or overzealous performance by the prosecution not only damages the public interest in the effective enforcement of the criminal laws, but may well result in reversible error where, for example, inadmissible evidence is brought before the jury or improper argument is presented. The suggested means for intervention are equally available to deal with prosecutorial incompetence.

132 See pp. 659-60 supra. For some examples of judicial intervention, see Bazelon, supra note 8 , at 16 . 
In the first instance, the judge's questions can be entirely innocuous and nonintrusive: Does counsel have further voir dire, wish to exercise any peremptory challenges, or object to questionable evidence being offered? Where an adverse witness appears to have had a strong impact, the court might well point out the fact and ask whether counsel is prepared to cross-examine, and whether pretrial investigation has disclosed a factual basis for cross-examination. Where conduct by the government might have had a prejudicial impact on the jury, inaction by defense counsel might lead the judge to ask counsel what he proposes be done about it. If counsel appears to be unprepared in the course of cross-examining adverse witnesses or examining his own, the court might call a recess, instruct and admonish counsel, and allow additional time for preparation. The court should also alert counsel to a possible default, ${ }^{133}$ such as the excusing of a witness who might be needed later, a failure to submit jury instructions, or a failure to make a timely motion or objection necessary to protect the record.

The court, however, is not to take over for defense counsel. The court cannot be expected to make evidentiary objections for the defense; but if counsel persists in failing to make valid objections, or is about to waive a critical objection such as one arising under the confrontation clause, the court should inquire whether it is counsel's intention to do so. Nor can the court be expected to take over the questioning of witnesses. While it has been said that the judge may have a duty to elicit those facts necessary to the clear presentation of the issues, which may in extraordinary cases include calling and examining witnesses and adducing evidence, his primary duty is to remain, as well as to appear, impartial; ordinarily he should refrain from extensive or pointed questioning of witnesses. ${ }^{134}$

Recourse to more drastic measures may sometimes be required. Suggesting or directing a change of counsel in the course of a trial is a step the court should take only when demonstrably necessary. The rights both of counsel and of the defendant must be carefully weighed against the demands of a fair trial. ${ }^{135}$

If, in the judge's view, the jury has become, as a result of

${ }^{133}$ See p. 657 supra.

${ }^{134}$ United States v. Brandt, I96 F.2d 653 (2d Cir. I952) (extensive questioning by the trial judge coupled with injudicious remarks constituted reversible error); see United States v. Liddy, 509 F.2d 428, 438, 440 (D.C. Cir. 1974) (en banc), cert. denied, 420 U.S. 9 II (I975); United States v. Wyatt, 442 F.2d 858 (D.C. Cir. I97I) (extensive questioning by trial judge which opened new areas of inquiry and gave undue eminence to others constituted error).

135 See pp. 659-60 supra. 
counsel's incompetence, so biased that a fair trial is no longer possible, it is appropriate to declare a mistrial. ${ }^{136}$ If granted at the request or with the consent of the defendant, it will not, in the absence of prosecutorial or judicial misconduct, bar a retrial. ${ }^{137}$

In the absence of consent, the judge must find a "high degree of necessity," warranting the subordination of the defendant's right to have the "trial concluded before the first jury impaneled" to the "public's interest in fair trials designed to end in just judgments." 138 In such a case, the court should make findings supporting the conclusion that the prejudice to the defendant's cause from counsel's incompetence was so substantial, and the alternative available so inadequate, that a mistrial must be granted. ${ }^{139}$

Finally, the judge has the option of ordering a new trial after a guilty verdict. Here the trial judge, however, acts in a capacity similar to that of an appellate court and is bound by the applicable standard of review for ineffective assistance.

6. Post-trial. - The right to effective assistance does not end with the trial. The Federal Rules of Criminal Procedure contemplate an active role for counsel in matters subsequent to trial. Rule 29 permits the court to enter judgment of acquittal either on motion of defendant or on its own motion. Rule 33 requires that a motion for a new trial be made within seven days after a verdict or within such further time as may be fixed during the seven day period. ${ }^{140}$ To prevent a default, therefore, the court may appropriately inquire whether counsel desires to present any post-trial motions.

The defendant is entitled to have counsel at sentencing to present any grounds that will aid the court in reaching a favorable disposition. ${ }^{141}$ To ensure effective performance, the

136 See generally United States v. Dinitz, 424 U.S. 600 (1976).

${ }^{137}$ Id. The Supreme Court has specifically rejected the notion that such consent must conform to the "knowing, intelligent, and voluntary" standard of Johnson v. Zerbst, 304 U.S. 458 (1938). United States v. Dinitz, 424 U.S. 600,609 n.II (1976) (trial court had declared mistrial with defendant's informal consent, after ejecting defendant's lead counsel for making a prejudicial opening statement in spite of court's prior warnings).

138 Arizona v. Washington, 434 U.S. 497,516 (1978).

${ }^{139}$ See United States v. Williams, 4II F. Supp. 854 (S.D.N.Y. 1976). See also United States v. Rogers, 47 I F. Supp. 847 (E.D.N.Y. 1979).

${ }^{140}$ If the ground for new trial is newly discovered evidence, rule 33 allows the motion within two years of final judgment.

141 United States v. Pinkney, 55I F.2d I24I (D.C. Cir. 1976); Gadsden v. United States, 223 F.2d 627 (D.C. Cir. I955), cert. denied, 350 U.S. 949 (1956); see DEFENSE Function, supra note 66, § 8.1, at 134-35:

(b) Defense counsel should present to the court any ground which will assist in reaching a proper disposition favorable to the accused. If a presentence report or summary is made available to the defense lawyer, he should seek to 
judge may inquire whether counsel has examined and takes exception to any part of the presentence report and has any additional facts or arguments that the court should consider in imposing sentence. The court should also protect the defendant against loss of the right to appeal by inadvertence or neglect. ${ }^{142}$ Rule 32 of the Federal Rules of Criminal Procedure now requires the court to advise the defendant of his rights to appeal and to apply for leave to appeal in forma pauperis after imposition of sentence following trial on a not guilty plea.

7. Feasibility. - Is it realistic to expect a judge, heavily burdened with a growing backlog of criminal cases, to indulge in the apparent luxury of pretrial conferences, sua sponte inquiries into the adequacy of counsel's preparation, and consideration of objections, defenses and posttrial motions? Even if these proposals are feasible in courts having light dockets, how could they be applied in large metropolitan courts where criminal cases are dispatched on an assembly line basis? Final answers to these questions must await experience. But this judge, at least, has found that thorough pretrial proceedings increase lawyer preparation, reduce trial time, and promote negotiated dispositions. Moreover, as lawyers become cognizant of the trial judge's willingness to intervene to assure effective representation, their performance should improve, thus reducing the number of instances in which intervention by the judge is necessary. Finally, the prophylactic approach suggested here should reduce the number of appellate reversals and new trials. In any event, the constitutional mandates for effective representation and fair trial procedures are facts, as is occasional incompetence of trial counsel. Courts must deal with the resulting problems, and to the extent the trial court is able to provide preventive relief, the interests of justice as well as economy and efficiency will be served.

\section{B. In the Civil Process}

I. Pretrial Phase. - Manifest incompetence in civil proceedings is no less a violation of counsel's professional obligations than in criminal cases, even if the constitutional im-

verify the information contained in it and should be prepared to supplement or challenge it if necessary. ...

(c) Counsel should alert the accused to his right of allocution, if any, and to the possible dangers of making a judicial confession in the course of allocution which might tend to prejudice his appeal.

$142 C f$. Rodriquez v. United States, 395 U.S. 327, 332 (1969) (defendant entitled to habeas relief where trial court had refused to permit him to make an oral motion to appeal in forma pauperis after imposition of judgment, resulting in failure to file timely notice of appeal, the Court saying: "At the very least, the trial judge should have inquired into the circumstances surrounding the attempt to make the in forma pauperis motion."). 
plications are more tenuous. The absence of a constitutional right to effective representation ${ }^{143}$ and the economic considerations which govern civil litigation make it more difficult to define the appropriate role for the trial judge with respect to incompetence. Nevertheless, if the adversary process is to operate fairly, it is incumbent upon the judge to monitor counsel's performance and intervene where egregious deficiencies

${ }^{143}$ The right to be represented by counsel in civil cases was well-established in English common law long before our Bill of Rights was enacted. See 4 W. BLACKSTONE, Commentaries * 355 . Indeed, the explicit mention of only criminal trials in the sixth amendment reflects the intention to reject the English rule forbidding counsel in felony criminal cases, see Powell v. Alabama, 287 U.S. 45, 6I-65 (1932), rather than an intention to deny such a right in civil cases, see Comment, Leis v. Flynt: Retaining a Nonresident Attorney for Litigation, 79 CoLUM. L. REV. 572, 581 n.65 (1979). Commentators have argued that the due process clause of the I4th amendment implies even a constitutional right to appointed counsel for indigents in civil cases involving property. E.g., Note, The Right to Counsel in Civil Litigation, 66 Colum. L. REv. 1322 (Ig66); Note, The Indigent's Right to Counsel in Civil Cases, 76 YaLE L.J. 545 (r967); $c f$. Betts v. Brady, 3I6 U.S. 455, 473 (r942) (dictum) (if due process were to require counsel in criminal cases, it would also mandate representation in civil cases involving property). But of. Gideon v. Wainwright, 372 U.S. 335 (1963) (overruling Betts on ground that counsel in criminal case is a "fundamental right"). No case has been found supporting a I4th amendment right to appointed counsel in civil cases.

Statutory provisions authorize judges to appoint counsel for a complainant under Title VII of the Civil Rights Act of 1964, 42 U.S.C. $\S 2000 e-5(f)(1)$ (1976), and to request an attorney to represent a person prosecuting or defending any action in forma pauperis, $28 \mathrm{id}$. $\$$ Igr5(d). But no authority exists for the payment of fees to appointed counsel in civil cases except as provided specifically by statute. Tyler v. Lark, 472 F.2d 1077, 1079 (8th Cir.), cert. denied, 414 U.S. 864 (x973); United States v. Dillon, 346 F.2d 633, 636 (9th Cir. 1965), cert. denied, 382 U.S. 978 (1966). Fees may be assessed as a part of a judgment in favor of a prevailing party in a suit under Title VII, 42 U.S.C. $\$ 2000 a-3$ (b) (I976), or a suit to enforce a person's constitutional rights, $i d$. $\$ \S \mathrm{I98} \mathrm{I}-\mathrm{I} 986$, $\mathrm{I988}$. In addition, under general common law principles, the court may direct the payment of fees out of a fund created or preserved by reason of the attorney's efforts. See, e.g., Mills v. Electric Auto-Lite Co., 396 U.S. 375, 389-97 (1970). See generally Dawson, Lawyers and Involuntary Clients: Attorney Fees From Funds, 87 HARV. L. REV. 597 (1974). Finally, in rare cases, the court may direct payment of fees by a losing party who has acted "in bad faith, vexatiously, wantonly, or for oppressive reasons." F.D. Rich Co. v. United States $e x$ rel. Indus. Lumber Co., 417 U.S. 116, 129 (1974); accord, Alyeska Pipeline Serv. Co. v. Wilderness Soc'y, 42I U.S. 240, 257-59 (1975). Whether, in view of the absence of funds to compensate him, an attorney may refuse the appointment is perhaps a question of theoretical more than practical interest. Some courts have found a duty so to serve to be among the traditional obligations of members of the bar. Tyler v. Lark, 472 F.2d 1077 (8th Cir.), cert. denied, 414 U.S. 864 (1973); United States v. Dillon, 346 F.2d 633 (9th Cir. 1965), cert. denied, 382 U.S. 978 (1966). Others have concluded that the $\mathrm{I}_{3}$ th amendment deprives the court of the power to require lawyers to serve involuntarily, either under 28 U.S.C. \& 1915(d) (1976), see United States v. Leser, 233 F. Supp. 535, 537-38 (S.D. Cal.), rev'd on other grounds, 335 F.2d 832 (9th Cir. 1964), cert. denied, 379 U.S. 983 ( 1965$)$, or under 42 U.S.C. $\$ 2000 e-5(f)(1)$ (1976), see In re Nine Applications for Appointment of Counsel in Title VII Proceedings, 475 F. Supp. 87 , 9I-92 (N.D. Ala. 1979). 
appear. The obligation of the judge to do so is accepted without question in those cases where parties are legally incompetent - most commonly cases involving minors or absent parties - and the judge is expected to make an independent judgment concerning their interests. ${ }^{144}$ Similarly, in class actions the judge is obligated to determine the adequacy of the representation of class members. ${ }^{145}$ It is, of course, not desirable for the judge to take on a similar obligation in civil litigation generally. That he sometimes bears the obligation to consider whether the interests of parties are adequately represented shows, however, that it is within his capacity to monitor the performance of counsel for manifest incompetence and take remedial steps when necessary.

Lawyers who have tried cases before a judge demonstrably partial to one side may rebel at the thought of judicial intervention, whether to criticize a lawyer or to help him. They may well feel that intervention - even if undertaken solely in the abstract interest of furthering the adversary process jeopardizes the appearance of impartiality. These are valid concerns that the trial judge must keep in mind. There is no reason, however, why the court, without sacrificing the appearance of impartiality, may not take steps to assure that counsel will be adequately prepared for trial, and, in the course of doing so, inquire about claims and defenses suggested by the facts before it; explore with counsel efficient and productive methods of discovery; clarify and define the issues; review the adequacy and admissibility of the testimonial and documentary proof proposed to be offered by each side; and generally oversee the progress of the litigation and keep counsel engaged so as to minimize the risks of defaults due to neglect. Especially in cases where the conduct of one or more attorneys creates doubt about their competence, the court should employ methods for ensuring that they are thoroughly prepared for trial. These include requiring the submission of pretrial memoranda on the issues to be tried, jury voir dire questions, detailed jury instructions, lists of witnesses with a summary of the testimony of each, lists of exhibits, proposed trial objections, and, in

144 See, e.g., Dacanay v. Mendoza, 573 F.2d I075 (9th Cir. r978); Blakely v. Johnson, 37 Ill. App. 3d Ir2, 345 N.E.2d 8I4 (I976); Wasson v. Wasson, 92 N.M. I62, 584 P.2d 713 (Ct. App. 1978). But see United States v. Weinstein, 5 II F.2d 622,628 (2d Cir.) (analogy to judge's role with respect to incompetents not sufficient to justify active participation in evidence production), cert. denied, 422 U.S. I042 (1975).

145 Fed. R. Crv. P. 23(c)(r). See also Gonzales v. Cassidy, 474 F.2d 67, 75-76 (5th Cir. I973); Cullen v. New York State Civil Serv. Comm'n, 435 F. Supp. 546, 560, 563-64 (E.D.N.Y.), appeal dismissed, 566 F.2d 846 (2d Cir. 1977). 
nonjury cases, narrative statements of the proposed direct testimony of the principal witnesses. ${ }^{146}$

The options for intervention in civil cases are similar to those described for the criminal process. ${ }^{147}$ The judge should not hesitate to inquire into counsel's trial strategy where the proposed witnesses and exhibits either fail to address the issues the judge sees in the case or where counsel's approach to the case seems to be deficient. As in criminal cases, these inquiries are better conducted before the trial begins than later. ${ }^{148}$ While a court-induced change of counsel will be rare, a judge ought to feel free to inform an attorney of any serious grounds to question his capacity to serve as trial counsel, perhaps suggesting the desirability of associating competent trial counsel.

2. The Trial Phase. - The judge's approach to monitoring performance and intervention during a civil jury trial will be similar to what has been described in connection with criminal trials. ${ }^{149}$ While the warning signals will also be similar, they will be more difficult to interpret because of the greater range of legitimate trial tactics in civil cases. Moreover, the judge will be both freer and more restrained than in criminal proceedings; freer because the risk of judicial error is less in a civil trial, and more restrained because incompetence may be more difficult to determine in a civil case. ${ }^{150}$ In bench trials, of course, the issue is far less critical inasmuch as there is no restraint on the court's participation in questioning witnesses and counsel to produce a record which it considers adequate for decision.

For the most part, what is suggested here is not a revolutionary departure from the practice of many judges who take an active part in the management of the litigation before

${ }^{146}$ See, e.g., Chapman v. Pacific Tel. \& Tel. Co., No. 78-3745 (9th Cir. Nov. 7, 1979); N.D. CAL. R. 235-5 to -ro. See generally, Schwarzer, Managing Civil Litigation - The Trial Judge's Role, 6r JUD. 400 (1978); Schwarzer, Beating the Trial Court Paper Chase, Litigation, Spring 1979, at 5.

147 See pp. 659-6o supra.

148 See p. 66I supra.

149 See pp. 66I-64 supra.

150 Also militating in favor of more liberal intervention is the reluctance of appellate courts to apply the "plain error" rule civil cases to review errors not preserved by objection at trial unless shown to be "fundamental" or "obvious." See generally Connor v. Finch, 43I U.S. 407, 421 n.19 (1977) (exceptional circumstances permit review); Piper v. Chris-Craft Indus., Inc., 430 U.S. I, 48 n.34 (1977) (matters of importance reviewable); Washington v. Davis, 426 U.S. 229,238 \& n.9 (1976). Inasmuch as the rule has not been codified or incorporated in rules of procedure, in courts other than the Supreme Court, it has only the standing of a common law principle. See, e.g, United States v. Tri-State Motor Transit Co., 550 F.2d 494 (gth Cir. 1977). See also notes 5 I, II2 supra. 
them. Nevertheless, difficult questions may arise when the apparent incompetence of one side seems to confer a substantive advantage on the other. What, for example, should the judge do when one side presents an apparently meritorious motion for summary judgment but fails to file the necessary affidavit to support a critical factual assertion? Only if the judge accepts the adversary process as an end in itself would he be satisfied to dispose of a contested matter substantially affecting a party's rights knowing that the outcome most likely is the result of one side's lack of attention or skill. It would seem preferable for the judge to do what he feels necessary to satisfy himself that both sides of the case have been adequately presented.

\section{CONCLUSION}

The judge's role in the adversary process does not include playing back-up counsel for any party. Nor does it require, however, indifference to the fairness with which the process operates. The judge has an inescapable responsibility for the maintenance of professional standards in the courtroom to ensure a fair trial. The discharge of that responsibility need not impair the adversary process; on the contrary, it should strengthen it. Promoting the vigorous and effective representation of both sides in the contest will help rather than hurt the process of finding the truth and achieving a just decision.

The judge, therefore should, in the words of Judge Charles E. Wyzanski, Jr., "[administer] his office true to its traditional limitations as well as to its aspirations." 151 He should consciously include among his judicial concerns the performance of counsel appearing before him. He should be sensitive to signals of inadequacy or default and respond in appropriate fashion if it appears that the result may be affected by the incompetence of counsel. That should be true even given crowded dockets and heavy case loads. If, in the short run, concern with incompetence of counsel were to impose some additional burdens on the trial courts, the long-term benefits from higher standards of lawyer performance should more than offset them.

151 Wyzanski, A Trial Judge's Freedom and Responsibility, 65 HARV. L. REV. I28I, I28I (1952). 